\title{
Assessing the Quality of Iron Ores for Bloomery Smelting: Laboratory Experiments
}

\author{
Ivan Stepanov 1,*(D), Konstantin Borodianskiy ${ }^{2}(\mathbb{D})$ and Adi Eliyahu-Behar 1,3 \\ The Institute of Archaeology, Ariel University, Ariel 40700, Israel; adieli@ariel.ac.il \\ 2 The Department of Chemical Engineering, Ariel University, Ariel 40700, Israel; konstantinb@ariel.ac.il \\ 3 The Department of Chemical Sciences, Ariel University, Ariel 40700, Israel \\ * Correspondence: ivanstep208@yandex.ru; Tel.: + 972-055-996-3577
}

Received: 21 November 2019; Accepted: 27 December 2019; Published: 29 December 2019

\begin{abstract}
There is fragmentary knowledge of iron ore sources exploited in the past for many regions including the Southern Levant. This missing information has the potential to shed light on political, economic, craft-production, and trading patterns of past societies. This paper presents the results of smelting experiments performed in graphite crucibles and a muffle furnace, using 14 iron ore samples from the Southern Levant, in an attempt to determine their suitability for smelting using ancient techniques. A range of analytical techniques, including optical and electron microscopy, Fourier-transform infrared spectroscopy, X-ray powder diffraction, and portable X-ray fluorescence were used to comparatively investigate the mineralogy and composition of the precursor iron ores and their smelting products: Iron bloom and slag. Several parameters attesting to the ability of a given ore to be successfully reduced and consolidated into a solid metal mass were quantified. The generated results highlight the significance of a 'correct balance' between iron oxides and other major elements in the smelting system in order to form fluid slag and a well-consolidated bloom. These data contribute to the understanding of factors, potentially influencing choices of iron ore exploitation by past human societies in the Southern Levant.
\end{abstract}

Keywords: iron ore; assay experiment; bloomery smelting; iron slag; southern Levant; muffle furnace

\section{Introduction}

Iron was produced in antiquity in most parts of the world, via a direct method-the bloomery process. Archaeological evidence, mainly as slag, for the use of the bloomery process, and secondary operations, has been identified in the southern Levant, Africa, and Europe from the late second millennium BCE to the mid/late second millennium AD [1-7].

In the bloomery process, iron is obtained through the reduction of ores in a small furnace usually operated by bellows, and sometimes via natural draft, using charcoal as fuel and as a reducing agent. Easily accessible and iron-rich ores (with more than 55-60 wt.\% of iron) were generally preferred due to the uneconomic loss of iron into slag during the process, resulting in low metal yield [7] (p. 87), [8] (p. 93), [9] (pp. 44-45). A further crucial aspect of the process consists of the fact that the composition of non-metallic impurities (gangue) significantly affects the viscosity of slag, favoring or hindering the reduction process [9] (p. 91-92), [10-12].

Identification of ore resources that were exploited in the past, therefore, has a particular significance as it can contribute to the understanding of the socio-technological factors affecting development of craft-production in the past societies. This identification can be achieved through the study and comparison of chemical and mineralogical composition of archaeological slags and ores, as well as through experimental smelting of ores from local geological outcrops to determine feasibility of their exploitation in the bloomery process [13-16] 
The assaying (i.e., small-scale experimentation to determine quality of an ore) has always been an important component of ancient technology, as it represented an easy and resource-efficient technique to predict and coordinate subsequent large-scale processing and smelting [17]. For past societies, this was an advantage, given that properties of materials could be grasped only empirically and use of metallic resources was often associated with high resource and labor costs (e.g., extraction, transportation, and processing of the ore and fuel, cf. iron production in Africa [18]). The assay furnaces described by Agricolla [19] are a historical example of methods traditionally used for cupellation of small amounts of costly argentiferous ores to predict the outcome of large-scale cupellation performed in larger furnaces set to a greater consumption of raw materials.

Determining the iron content and the quality of iron ores, prior to large-scale bloomery smelting, thus, is highly advantageous. Significantly, despite the common occurrence of iron ores in nature, knowledge about the types of deposits exploited in the past often remains limited and poorly understood. In fact, for some regions of the Ancient Near East, for example, south-eastern Arabia and Cyprus, there is still a lack of evidence about indigenous iron ore exploitation, although certain types of iron-rich rocks (e.g., gossans) exist in these regions [20-23]. Whereas in other regions, such as the southern Levant, evidence of past ore exploitation is only known so far from the Mugharet el-Wardeh deposit in the Ajloun, Jordan [5,24], although this is certainly not the only ore deposit in the region.

In this paper, we present the results of a series of iron smelting experiments, conducted in a muffle furnace using graphite crucibles. Fourteen ore samples from three geological regions of the southern Levant were used as a test case. Among these samples, only three (Ajloun, see below) represent ores that are known to have been exploited in antiquity. Bloom and slag produced in each experiment were studied in correlation with the ore chemical composition and mineralogy. Results of conducted analysis are used to reflect on the conditions needed to implement in order to allow smelting of these ores in a bloomery furnace, accounting for the inherited differences between the assaying system and the bloomery furnace. The overall purpose of this research methodology was to create the scientific foundation for a set of iron smelting experiments, conducted on a much larger scale using the more authentic shaft bloomery furnace (Field bloomery smelting experiments are ongoing and will be discussed in forthcoming publications).

\section{Materials and Methods}

\subsection{Iron Ores}

A total of 14 ore samples from three different geological ore groups were tested; epigenetic ores of the Negev region, Israel, hypogene ores from the Ajloun region, Jordan, and iron-rich nodules from the Arabah valley (Timna and Wadi Amram), Israel (Figure 1). Samples were chosen from a larger collection of iron ores from various regions in Israel. The Ajloun samples were tested as they represent the only source so far known to have been exploited in the past. Given the common heterogeneity of the geological ore bodies, several samples were assayed for most deposits (Table 1). 


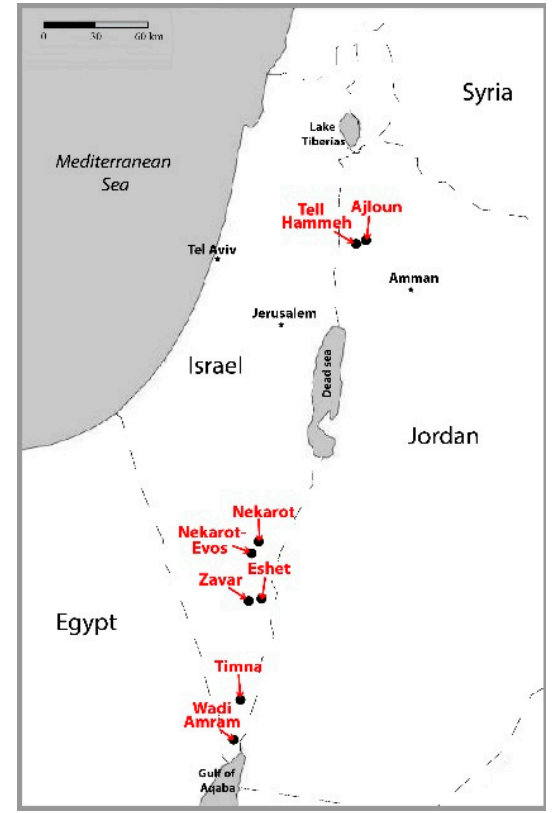

Figure 1. Location of iron ore deposits and occurrences of Southern Levant. Negev: Nekarot, Nekarot-Evos, Zavar, Eshet; Arabah: Timna, Wadi Amram; Ajloun.

Table 1. Iron ores selected for assaying experiments, morphology, and mineralogical composition identified by FTIR, XRD, OM, and SEM.

\begin{tabular}{|c|c|c|c|c|c|c|c|c|c|}
\hline \multirow{2}{*}{$\begin{array}{l}\text { Sample } \\
\text { No. }\end{array}$} & \multirow{2}{*}{$\begin{array}{l}\text { Sample } \\
\text { Name }\end{array}$} & \multirow{2}{*}{ Deposit } & \multirow{2}{*}{ Morphology } & \multicolumn{6}{|c|}{$\begin{array}{c}\text { Main Mineralogical Phases by FTIR, XRD, } \\
\text { OM/SEM }\end{array}$} \\
\hline & & & & $\mathrm{Hm}$ & Gth & Cal & Gy/Anh & Qtz & Brt \\
\hline 2 & Negev-2 & Nekarot-Evos & Black dense ore & & +++ & + & $\operatorname{tr}$ & + & $\operatorname{tr}$ \\
\hline 3 & Negev-3 & Zavar & $\begin{array}{l}\text { Black-brown dense ore } \\
\text { with conchoidal fracture }\end{array}$ & + & +++ & & $\operatorname{tr}$ & + & $\operatorname{tr}$ \\
\hline 4 & Negev-4 & Zavar & Black-brown dense ore & + & +++ & & + & & \\
\hline 5 & Negev-5 & Nekarot & Black dense ore & + & +++ & $\operatorname{tr}$ & $\operatorname{tr}$ & ++ & + \\
\hline 6 & Negev-6 & Nekarot & Black dense ore & + & +++ & $\operatorname{tr}$ & $\operatorname{tr}$ & ++ & $\operatorname{tr}$ \\
\hline 7 & Negev-7 & Nekarot & $\begin{array}{l}\text { Rusty brown ore with } \\
\text { black banding }\end{array}$ & + & +++ & + & & ++ & \\
\hline 9 & Negev-9 & Eshet & Brown rusty ore & ++ & ++ & ++ & & + & \\
\hline 10 & Ajloun-1 & Warda & Reddish-brown rusty ore & ++ & + & ++ & & + & \\
\hline 11 & Ajloun-2 & Warda & $\begin{array}{l}\text { Black dense ore with } \\
\text { white calcite veins }\end{array}$ & +++ & + & + & & $\operatorname{tr}$ & \\
\hline 12 & Ajloun-3 & Warda & $\begin{array}{l}\text { Brown dense ore with } \\
\text { conchoidal fracture }\end{array}$ & & +++ & $\operatorname{tr}$ & & + & \\
\hline 13 & Arabah-1 & Wadi Amram & Iron nodule & + & + & $\operatorname{tr}$ & & +++ & \\
\hline 14 & Arabah-2 & Timna & Iron nodule & + & + & & $\operatorname{tr}$ & +++ & \\
\hline
\end{tabular}

$+;++;+++$-indicate relative degree of mineral abundance in the sample. Abbreviations: tr: Only localized occurrence of mineral phase; Hm—hematite, Gth—goethite, Cal—calcite, Gy/Anh—gypsum/anhydrite, Qtz—quartz, Brt-barite, tr.

The epigenetic and hypogene iron mineralization are associated with major trending faults related to the Dead Sea transform (DST). Epigenetic ores mostly occur in the northern Negev region, Israel [23,25,26], while hypogene ores are known from the upper Jordan valley in the Ajloun region, in north-western 
Jordan $[27,28]$. These two geological formations are hosted in carbonate rocks, with locally varying, but broadly similar mineralogy and characterized by generally high iron content. It should be noted that evidence for exploitation of these deposits has been so far identified, only at Mugharet el-Wardeh, in the Ajloun region, dating to the Iron Age and possibly throughout the Islamic period [5,24,28].

The iron-rich nodules from the Arabah valley were formed through epigenetic remobilization, weathering, and erosion of the primary Cu-Fe sulphidic ores [29] (pp: 63-68). These ores often comprise an average of 20-30 wt.\% iron and occasionally higher [23].

\subsection{Assaying Setup}

To account for ore heterogeneity, 40-80 g of ore was initially ground and sieved down 0.1-0.5 mm size, of which ca. $25 \mathrm{~g}$ was roasted. Smelting and roasting (with or without charcoal, respectively), were conducted using an electric muffle/furnace (Nabertherm Top 16, Lilienthal, Germany). The successful parameters of the assaying procedure are summarized in Table 2. For roasting, ground ore was placed within a $900 \mathrm{~mL}$ graphite crucible and heated to $600{ }^{\circ} \mathrm{C}$ for $2 \mathrm{~h}$. After roasting, the loss of mass was recorded, usually in the range of 8-10 wt.\%.

Table 2. The determined optimal parameters of iron ore smelting (assaying), using graphite crucibles and a muffle furnace.

\begin{tabular}{|c|c|c|c|c|c|}
\hline $\begin{array}{c}\text { Amount of } \\
\text { Roasted Ore, g. }\end{array}$ & $\begin{array}{l}\text { Amount of } \\
\text { Charcoal, g. }\end{array}$ & $\begin{array}{l}\text { Ore Fraction } \\
\text { for Roasting } \\
\text { and Smelting }\end{array}$ & $\begin{array}{l}\text { Charcoal Fraction } \\
\text { for Smelting }\end{array}$ & $\begin{array}{c}\text { Roasting, } \\
\text { Temperature and } \\
\text { Time }\end{array}$ & $\begin{array}{c}\text { Smelting, } \\
\text { Temperature and } \\
\text { Time }\end{array}$ \\
\hline \multirow[t]{2}{*}{20} & \multirow[t]{2}{*}{10} & \multirow[t]{2}{*}{$<0.5 \mathrm{~mm}$} & \multirow[t]{2}{*}{$\begin{array}{c}0.5-1 \mathrm{~mm}(8 \mathrm{~g}) \\
\text { dust }<0.5 \mathrm{~mm}(2 \mathrm{~g})\end{array}$} & $\begin{array}{c}20->600{ }^{\circ} \mathrm{C}(1 \mathrm{~h}) ; \\
\text { keep at } 600{ }^{\circ} \mathrm{C}(2 \mathrm{~h})\end{array}$ & $\begin{array}{l}20->800^{\circ} \mathrm{C}(1 \mathrm{~h}) ; \\
800->1200^{\circ} \mathrm{C}(1 \mathrm{~h}) \text {; } \\
1200->1250^{\circ} \mathrm{C}(1 \mathrm{~h}) \text {; } \\
\text { keep at } 1250^{\circ} \mathrm{C}(1 \mathrm{~h})\end{array}$ \\
\hline & & & & Total time: $3 \mathrm{~h}$ & Total time: $4 \mathrm{~h}$ \\
\hline
\end{tabular}

Smelting was conducted at a max temperature of $1250^{\circ} \mathrm{C}$ dwelling for $1 \mathrm{~h}$. The graphite crucible was loaded with the charge in layers as schematically shown in Figure 2a. We used commercially available charcoal. The bottom of the crucible was covered with $2 \mathrm{~g}$ of charcoal powder $(<0.5 \mathrm{~mm})$ to prevent from alloying with the reduced iron. On top, a layer of $5 \mathrm{~g}$ of charcoal ground and sieved to 0.5-1 mm size, was placed, followed by ca. $20 \mathrm{~g}$ layer of roasted ore, and another layer of charcoal (0.5-1 mm). Upon the completion of the smelting sequence, samples were left to cool inside the furnace and were removed on the next day.
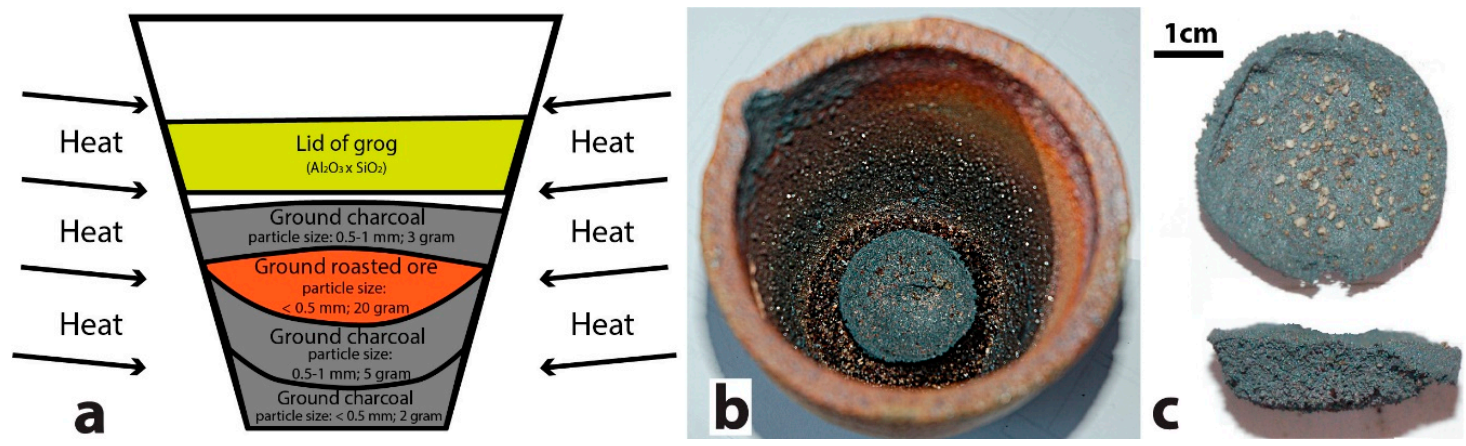

Figure 2. Visualization of crucible setup and final smelting product: (a) Schematic representation of the ore-charcoal layout inside the crucible; (b) typical appearance of the final smelting product (bloom) after completion of the experiment; (c) bloom: Top and lateral view (sample Negev-1). 


\subsection{Characterization Methods}

Samples of ores were characterized for their chemical and mineralogical composition, using a range of analytical techniques, such as portable $X$-ray fluorescence (pXRF), Fourier-transform infrared spectroscopy (FTIR), X-ray powder diffractometry (XRD), and optical (OM) and scanning electron microscopy (SEM-EDS). Assaying results, bloom, and associated slag were mostly characterized by optical and electron microscopy.

\subsubsection{Portable X-Ray Fluorescence (pXRF)}

Bulk chemical composition of ore samples was measured by pXRF, using a Thermo Gould III instrument (Thermo Fisher Scientific, Waltham, MA, USA) with a silver (Ag) anode and a set of secondary targets. Quantification was made using a "mining" calibration set in the system. Approximately $3 \mathrm{~g}$ of each sample were homogenized and ground to a fine powder (smaller than $0.5 \mathrm{~mm}$ ) using an agate mortar and pestle. Samples were placed in an XRF cup with a 4-micron Prolene film. For several ore samples, bulk XRF analyses were corroborated by spot analysis of polished sections using SEM-EDS. However, pXRF had an advantage over SEM as it allowed to measure a larger, homogenized sample. Precision and accuracy were tested by repeated analyses of three standard reference materials (Table 3). Under these conditions, accuracy is generally better than $10 \%$ for elements present in the analyte at more than $5 \mathrm{wt}$.\%. However, the data for low-Z elements such as Si and Al, especially when present in low quantities, were treated with caution due to a relatively low sensitivity of pXRF.

\subsubsection{X-Ray Powder Diffraction (XRD)}

XRD was used to determine the major mineralogical components of the ores. Analysis was carried out using a Rigaku SmartLab SE instrument, with Cu-Ka radiation at $40 \mathrm{kV} / 50 \mathrm{~mA}$. Powdered samples (prepared as pellets) were measured in a 2Theta/Theta mode between 10/15-75 degrees, at a scan speed of $5^{\circ} / \mathrm{min}$ and a scan step of $0.02^{\circ}$.

\subsubsection{Fourier Transforms Infrared Spectroscopy (FTIR)}

FTIR was used as a complementary method for XRD, for mineralogical characterization of the ores. Representative spectra were obtained by grinding a few tens of micrograms of powdered ore using an agate mortar and pestle. The ground sample was then mixed with $\mathrm{KBr}$ (IR-grade) to produce a $5 \mathrm{~mm}$ diameter pellet using a press. Spectra were collected between 4000 and $400 \mathrm{~cm}^{-1} \mathrm{at}^{\mathrm{cm}} \mathrm{cm}^{-1}$ resolution for 32 scans using a Thermo Nicolet iS5 spectrometer (Thermo Fisher Scientific, Waltham, MA, USA). The interpretation of spectra is based on a library of mineral standards. The advantage of this method lies in the easy and quick gathering of information and its sensitivity to disordered phases, thus complementary to XRD. 
Table 3. Chemical analyses by portable X-Ray fluorescence of 14 ore samples used in the experiments.

\begin{tabular}{|c|c|c|c|c|c|c|c|c|c|c|c|c|c|c|c|c|c|c|c|c|c|}
\hline \multirow{2}{*}{\multicolumn{2}{|c|}{ Sample No }} & $\mathrm{MgO}$ & $\mathrm{Al}_{2} \mathrm{O}_{3}$ & SIO2 & $\mathrm{P}_{2} \mathrm{O}_{5}$ & $\mathrm{SO}_{3}$ & $\mathrm{~K}_{2} \mathrm{O}$ & $\mathrm{CaO}$ & $\mathrm{TiO}_{2}$ & $\mathrm{~V}_{2} \mathrm{O}_{5}$ & $\mathrm{MnO}$ & $\mathrm{FeO}$ & $\mathrm{BaO}$ & Tot & $\mathrm{Zr}$ & $\mathrm{Sr}$ & $\mathrm{Cu}$ & $\mathbf{P b}$ & As & $\mathrm{Zn}$ & $\mathrm{Ni}$ \\
\hline & & & & & & & & wt. $\%$ & & & & & & & & & & ppm & & & \\
\hline \multicolumn{2}{|c|}{ Negev-1 } & & 1.1 & 3.3 & & 1 & 0.1 & 1.5 & & 0.2 & & 79.7 & 0.66 & 87.6 & & 188 & 694 & & & 214 & 406 \\
\hline \multicolumn{2}{|c|}{ Negev-2 } & & 0.9 & 2.2 & & 1.5 & 0.2 & 4.6 & 0.1 & 0.3 & & 77.7 & 0.12 & 87.6 & & 122 & 666 & & 65 & 311 & 185 \\
\hline \multicolumn{2}{|c|}{ Negev-3 } & 3.1 & 0.9 & 5.7 & & 0.9 & 0.1 & 0.5 & 0.1 & & & 80.1 & 0.17 & 91.6 & & 106 & 781 & 89 & 46 & 524 & \\
\hline \multicolumn{2}{|c|}{ Negev-4 } & 1.7 & 1 & 3.2 & & 1.1 & 0.1 & 0.5 & & & 0.2 & 84.3 & 0.05 & 92.3 & 11 & 38 & 649 & 276 & & 1174 & \\
\hline \multicolumn{2}{|c|}{ Negev-5 } & & 1.4 & 9 & 0.1 & 4.6 & 0.1 & 0.8 & & 0.5 & 0.1 & 67.7 & 4.7 & 89.1 & & 380 & 921 & & & 630 & 382 \\
\hline \multicolumn{2}{|c|}{ Negev-6 } & & 1.8 & 8.8 & 0.2 & 1.1 & 0.2 & 2.5 & 0.1 & 0.7 & & 73.8 & 0.68 & 90.0 & 21 & 114 & 826 & & & 782 & 252 \\
\hline \multicolumn{2}{|c|}{ Negev-7 } & & 0.7 & 30.6 & 0.1 & 0.4 & 0.1 & 6.1 & & 0.2 & & 47 & 0.23 & 85.5 & 11 & 125 & 592 & & 32 & 346 & 291 \\
\hline \multicolumn{2}{|c|}{ Negev-8 } & 1.9 & 1.4 & 4.6 & 0.1 & 2.9 & 0.2 & 1.3 & 0.1 & 0.1 & 0.1 & 75.2 & & 88.0 & 20 & 73 & 706 & & 387 & & \\
\hline \multicolumn{2}{|c|}{ Negev-9 } & & 1.2 & 1.6 & & 1.4 & 0.2 & 12.1 & & & 0.3 & 67.4 & 0.04 & 84.3 & 13 & 128 & 718 & & 363 & & \\
\hline \multicolumn{2}{|c|}{ Ajloun-1 } & & 0.7 & 1.7 & & 0.4 & 0.1 & 16.1 & 0.1 & 0.1 & & 56.5 & & 75.7 & 16 & 36 & 668 & & 235 & 53 & 159 \\
\hline \multicolumn{2}{|c|}{ Ajloun-2 } & & 0.8 & 1.6 & & 0.5 & 0.2 & 6 & & & & 85.5 & & 94.6 & & & 780 & & 77 & 210 & 164 \\
\hline \multicolumn{2}{|c|}{ Ajloun-3 } & 1.8 & 0.8 & 0.6 & & 0.3 & 0.1 & 0.1 & & & & 88.4 & & 92.1 & & & 707 & & & & \\
\hline \multicolumn{2}{|c|}{ Arabah-1 } & 1.6 & 1.2 & 32.8 & 0.1 & 0.8 & 0.1 & 0.3 & 0.1 & 0.1 & & 53.9 & 0.45 & 92.0 & 29 & 104 & 1188 & 1382 & 205 & 3492 & 433 \\
\hline \multicolumn{2}{|c|}{ Arabah-2 } & 1.4 & 0.7 & 38.4 & & 3 & 0.1 & 1.1 & 0.2 & & & 42.9 & & 87.9 & 265 & 40 & 404 & 18 & & & 67 \\
\hline \multirow{2}{*}{ STD Iron Pl3.20 } & Meas. value & & & 6.2 & & & 0.2 & 0.3 & & & & 92.3 & & 99.0 & & & 852 & 15 & & 20 & \\
\hline & Cert. value & & & 5.3 & & & 0.1 & 0.1 & & & & 96.9 & & 102.4 & & & 15 & & & & \\
\hline \multirow{2}{*}{ STD GSS-1 } & Meas. value & 0.9 & 8.9 & 54.7 & 0.3 & & 1.8 & 1.6 & 0.7 & 0.02 & 0.2 & 4.9 & 0.03 & 74.1 & 242 & 154 & 198 & 100 & 34 & 670 & 20 \\
\hline & Cert. value & 1.8 & 14.2 & 62.5 & 0.2 & & 2.6 & 1.7 & 0.8 & 0.02 & 0.2 & 4.7 & 0.07 & 88.9 & 241 & 135 & 22 & 91 & 33 & 552 & 26 \\
\hline \multirow{2}{*}{ STD GBW07112 } & Meas. value & 3.5 & 14.2 & 34.8 & & 1.3 & 0.2 & 9.6 & 5.7 & 0.2 & 0.2 & 21.3 & 0.02 & 91.1 & 29 & 612 & 463 & 5 & & 118 & 69 \\
\hline & Cert. value & 5.3 & 14.1 & 35.7 & & 0.9 & 0.2 & 9.9 & 7.7 & 0.1 & 0.2 & 22.3 & 0.01 & 96.5 & 16 & 556 & 28 & & 10 & 119 & 93 \\
\hline
\end{tabular}

STD—indicate certified standard material, Meas. Value—measured value, Cert. value—certified value. For STD Iron Pl3.20, certified value was taken from [1], for STD GSS-1, certified value was taken from [30]; for STD GBW07112, certified value was taken from [31]. 


\subsubsection{Optical and Electron Microscopy (OM and SEM-EDS)}

Optical and electron microscopy were used for the identification of major ore minerals and analysis of phase, chemical composition, and microstructure of both ores and results of the assaying experiments. Samples were prepared according to standard metallographic procedures, by mounting cut sections in Epoxy resin and polish down to 1 micron.

In order to determine the bloom degree of consolidation (see below) and quantify the percent area of the main components present, two steps were conducted; the first step was used to assess the percentage area of metallic iron throughout the full section of each sample using pixel counting function in Adobe Photoshop (CS5, 12.1, San Jose, CA, USA). Then, a second, more accurate step was undertaken using a Zeiss Axioscope5 (Jena, Germany), polarized microscope equipped with Clemex vision lite software (8.0.197, Longueuil, QC, Canada) to assess the percent area of each of the present phases, including pores, reduced metal, iron oxide, silicate slag, and quartz. Analysis was performed on an average of 6 micrographs $(500-1100 \mu \mathrm{m} \times 350-700 \mu \mathrm{m}$ in size) for each sample.

Further mineralogical and phase analysis, including slag bulk chemical composition, was conducted using A Tescan MAIA3 electron microscope (SEM, Brno, Czech Republic) equipped with an energy dispersive X-ray spectrometer (EDS) system by Oxford Instruments (Abingdon, UK) with an X-MaxN detector. Multiple areas of $20 \mu \mathrm{m}^{2}-200 \mu \mathrm{m}^{2}$ average size from each sample were studied.

\section{Results}

Fourteen ore samples were successfully assayed to produce reduced metallic iron. Analysis of the ores and smelting products enabled us to correlate between the ore composition, bloom, and slag formation, and to generally determine the suitability of each of the ore samples for use in a bloomery process.

\subsection{Characterization of Iron Ores}

\subsubsection{Negev Ores}

The chemical composition of most of the Negev ore samples is highly iron-rich (FeO 70-80 wt.\%) and contains $\mathrm{Ca}$ and $\mathrm{Si}$ as major non-metallic elements. Elevated levels of $\mathrm{S}, \mathrm{Ba}$, and $\mathrm{V}$ are also present in some of the samples and can be considered signifying elements for these ores (Table 3). Mineralogy is comprised of goethite as the main ore mineral that can be occasionally intergrown with hematite (Figure 3a). Quartz and calcite are the main associated non-metallic minerals, often in the form of lenses or veins, and small amounts of gypsum and barite are also commonly present (Figure 3a-d). In sample Negev-9, pseudomorphs of hematite after hexagonal calcite crystals were identified (Figure 3b). The OM identification of main ore minerals is further confirmed by both XRD and FTIR analyses and is summarized in Table 1. Figures 4 and 5 show representative XRD diffraction patterns and FTIR spectra of four samples, depicting the major components of each ore group. Interestingly, XRD analyses commonly display broadening of goethite peaks, which indicates nanocrystalline grain size or poor crystallinity of goethite (Figure 4a). In addition to the main phases, diffraction peaks corresponding to the minerals of barite and gypsum were identified in samples Negev-5 and Negev-8 (Figure 4a,b). Overall, Negev ores are rich in iron oxide minerals, containing relatively small amounts of gangue minerals such as quartz, calcite, gypsum, and barite, suggesting their suitability for bloomery iron smelting (Figure 3a,d, Supplementary Figures S28-S36). 

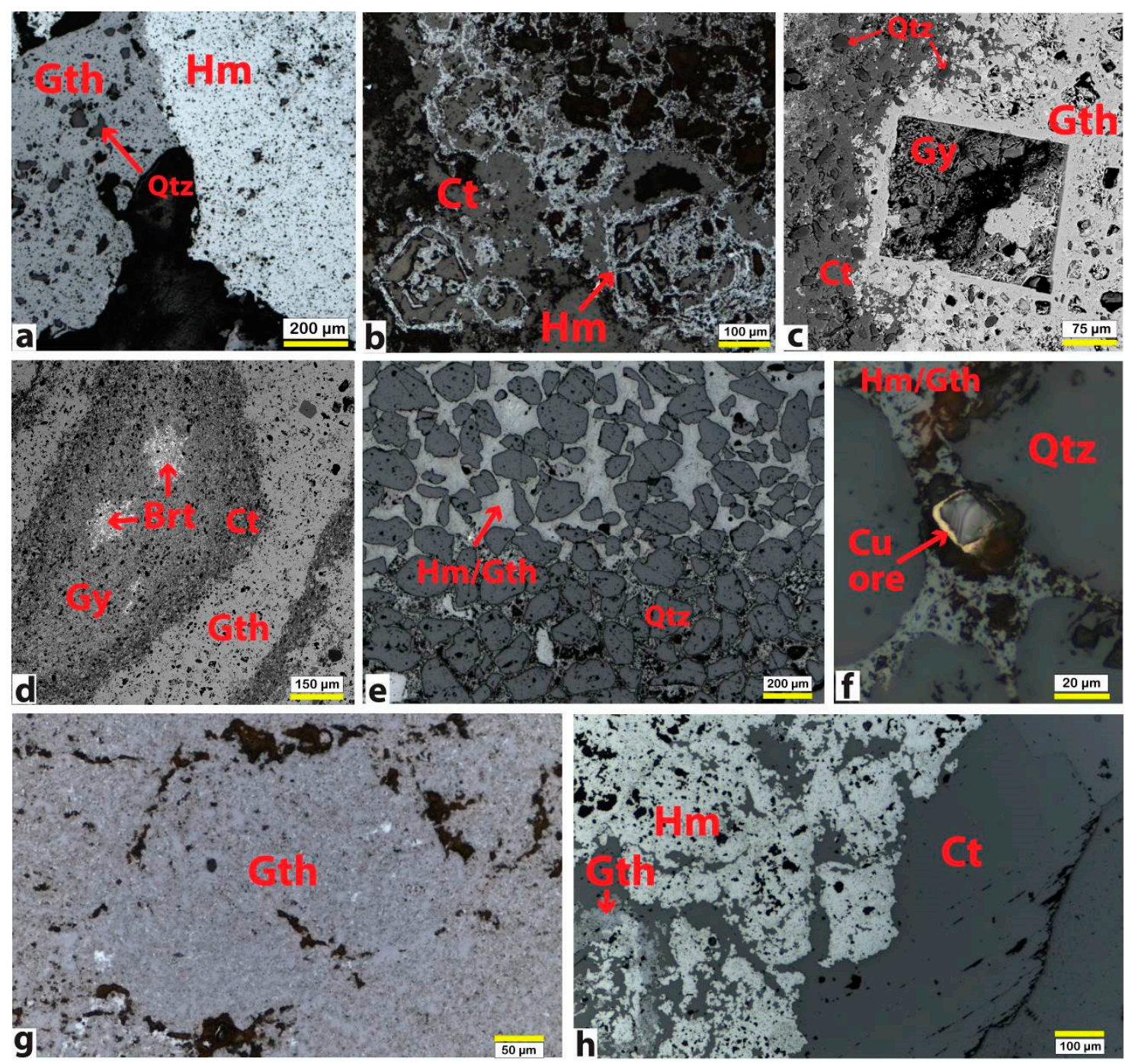

Figure 3. Microstructures of assayed ores: (a) OM. Negev-6. Intergrowth of goethite (Gth) and hematite $(\mathrm{Hm})$. Goethite-rich part contains significant amount of quartz (Qt); (b) OM. Negev-9. Pseudomorphs of hematite after calcite (Ct); (c) SEM Backscattered Electron Imaging (BEI). Negev-2. To the right: Crystal of gypsum (Gy) in goethite matrix. To the left: The area composed of calcite and quartz; (d) SEM-BEI. Negev-2. Lens enriched with calcite, gypsum, and barite (Brt, white core of the lens); (e) OM. Arabah-2. Banded structure of the ore. Upper layer consists of quartz present in the matrix of hematite and goethite. (f) OM. Arabah-2. Copper ore (Cu ore) mineral of the ore; (g) OM. Ajloun-3. Ore dominated by goethite; (h) OM. Ajloun-2. Ore dominated by hematite, with minor presence of goethite, in the matrix of calcite. 
Negev-8
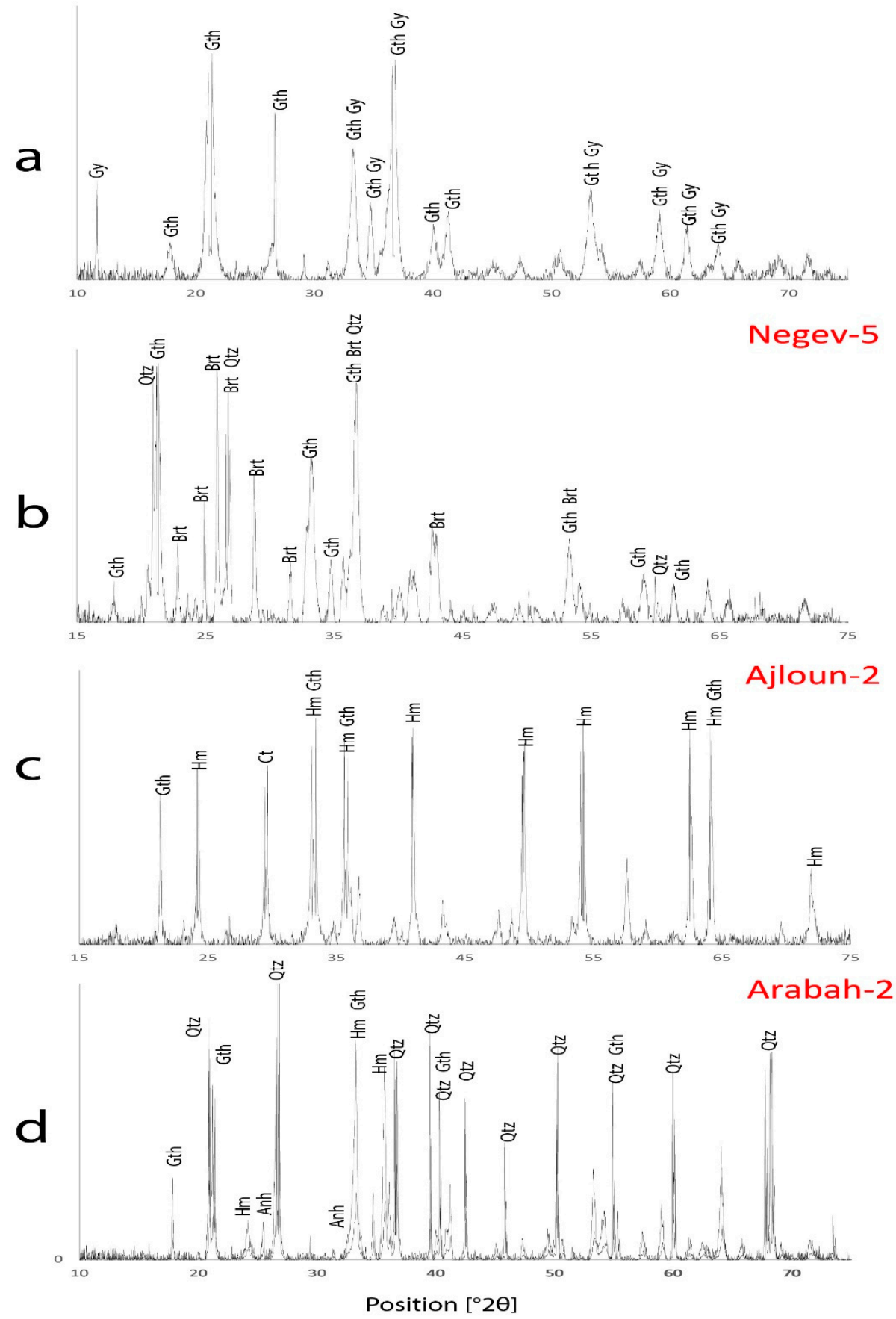

Figure 4. Examples of XRD diffraction patterns of analyzed iron ore samples with peaks corresponding to specific minerals: (a) Negev-8. Ore dominated by goethite (Gth) with some amount of gypsum (Gy); (b) Negev-5. Ore dominated by goethite with some amount of barite (Brt) and quartz (Qtz); (c) Ajloun-2. Ore dominated by hematite $(\mathrm{Hm})$, with some amount of goethite and calcite $(\mathrm{Ct})$; (d) Arabah-2. Ore of goethite and hematite, with significant amount of quartz and minor amount of anhydrite (Anh). 

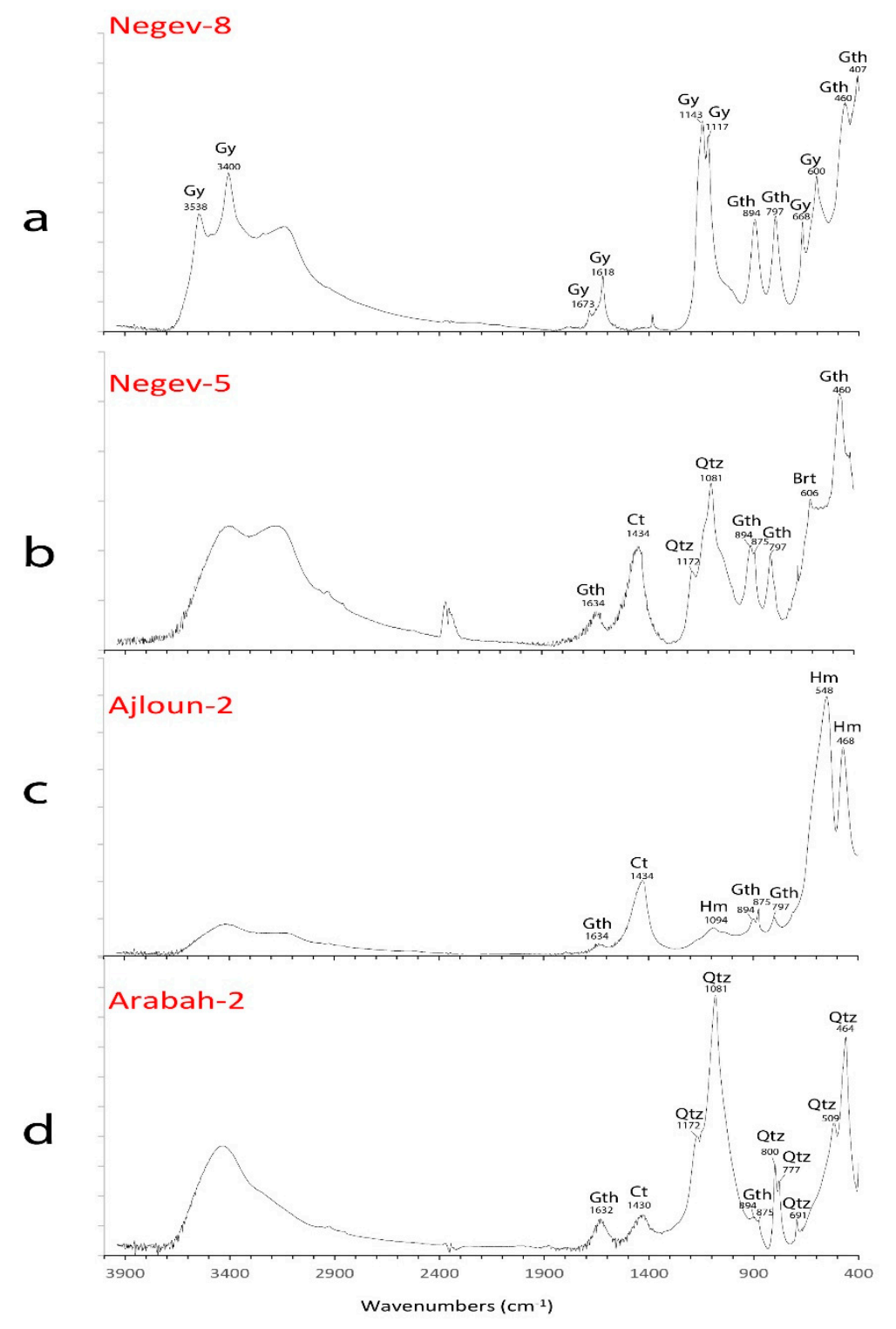

Figure 5. Examples of FTIR spectra of some analyzed iron ore samples with peaks corresponding to specific minerals: (a) Negev-8. Ore dominated by goethite (Gth) with some amount of gypsum (Gy); (b) Negev-5. Ore dominated by goethite with some amount of barite (Brt) and quartz (Qtz); (c) Ajloun-2. Ore dominated by hematite $(\mathrm{Hm})$, with some amount of goethite and calcite $(\mathrm{Ct}) ;(\mathbf{d})$ Arabah-2. Ore of goethite, with significant amount of quartz and minor amount of calcite.

\subsubsection{Ajloun Ores}

XRF analyses of two of the Ajloun ore samples show extremely high iron content (FeO 86-88 wt.\%, Table 3) and elevated $\mathrm{CaO}$ levels (16 and $6 \mathrm{wt} . \%$ in Ajloun 1 and 2), which supports high amount of iron oxide minerals and the relatively small portion of gangue dominated by calcite as major associated mineral in these samples, as observed by the optical microscopy (Figure $3 \mathrm{~h}$, Supplementary Figures S39-S41). The dominant ore mineral in Ajloun-1 and Ajloun-2 samples is hematite, while goethite is dominant in Ajloun-3 (Figure 3g,h). Sulphur $\left(\mathrm{SO}_{3}\right)$ and barium contents $(\mathrm{BaO})$ of Ajloun ores are generally lower than those of Negev ores, which correlates with the lack of gypsum and barite in the former (Table 3). XRD and FTIR analyses confirm the presence of hematite, goethite, calcite, and quartz in the Ajloun samples revealing characteristic peaks of these minerals (Figures 4 and 5, and Supplementary Figures S1-S27). 


\subsubsection{Arabah Ores}

The two samples of ferruginous nodules from the Arabha Valley (Timna and Wadi Amram) reveal an average of ca. $45-50 \mathrm{wt}$ \% $\mathrm{FeO}$, as goethite and hematite, significant levels of $\mathrm{SiO}_{2}(33-38 \mathrm{wt}$. \%), as quartz sand, and low levels of $\mathrm{CaO}$ (0.3-1.1 wt.\%), correlating with the lack of carbonate minerals (Table 3 and Figure 3e). The microstructure of Arabah ores indicates low portion of iron oxide mineral versus high portion of quartz-dominated gangue, suggesting potential difficulties for smelting of these ores in a bloomery furnace (Figure 3e, Supplementary Figures S37-S38). The OM investigation of the Arabah-2 sample also reveals accessory presence of copper ore (Figure 3f), while XRD and FTIR analyses of this sample confirm abundance of quartz, and minor presence of anhydrite and calcite (Figures $4 \mathrm{f}$ and $5 \mathrm{f}$ ).

Overall, considering the natural variability of the studied ores, the small number of samples, and the data available, results of ore analysis are generally in agreement with previously published data [23,25-28], [29] (pp: 63-68).

\subsection{Characterization of Assaying Results}

The assaying experiments proved successful and allowed for reduction of the ores producing heterogeneous, porous masses of metallic iron (i.e., bloom), slag, and relics of partially reduced ore. Although the assaying method is different from the bloomery smelting technique due to the absence of downward descend of the ore and the lack of hot air convection, it allows to produce some general observations about the feasibility of smelting of these ores in a bloomery furnace.

Despite common heterogeneity of all produced blooms, they differ from each other in their properties, particularly porosity, amount of reduced metal, and chemical and mineralogical composition of the slag. Since the parameters of all smelting experiments were kept constant, the apparent variability must be directly related to differences in ore composition.

Three main parameters were considered and quantified in order to asses consolidation degree of the experimental bloom - the ability of the reduced iron to consolidate (coalesce) into a single mass:

1. Volume of reduced iron;

2. Porosity of the bloom;

3. Volume, composition, and mineralogy of the slag.

\subsubsection{Bloom Consolidation}

Figure 6 shows representative microstructures of blooms from each group. At low magnification, the general porosity and network of metallic iron can be seen, while higher magnifications show the relations between the various phases identified. Based on the above specified parameters, blooms were classified into three different grades; well $\left(\mathrm{W}_{\mathrm{CB}}\right)$, moderately $\left(\mathrm{M}_{\mathrm{CB}}\right)$, and poorly $\left(\mathrm{P}_{\mathrm{CB}}\right)$ consolidated blooms (Table 4). 

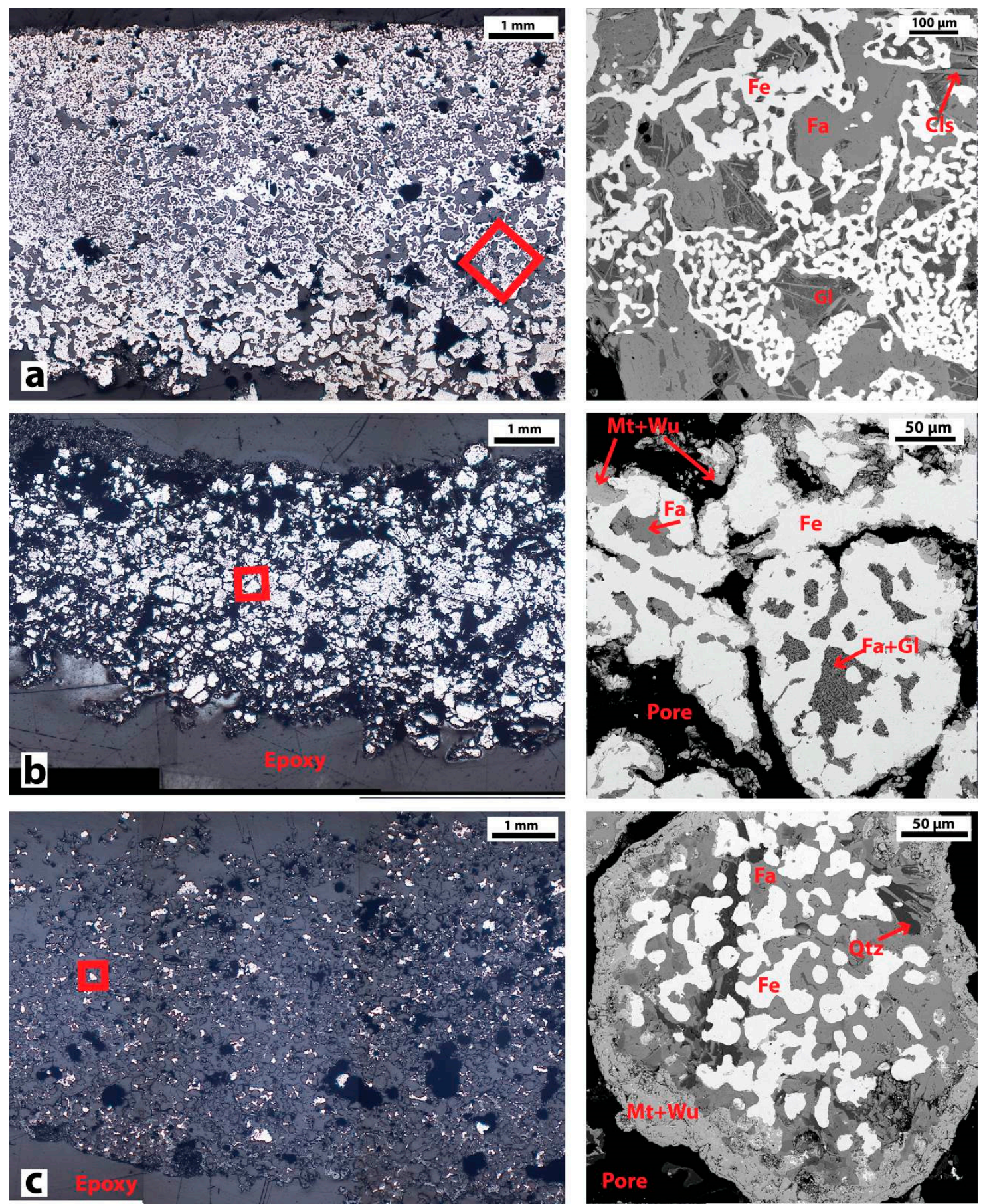

Figure 6. Typical microstructures of $\mathrm{W}_{\mathrm{CB}}, \mathrm{M}_{\mathrm{CB}}$, and $\mathrm{P}_{\mathrm{CB}}$. Left: Optical microscopy overview image of bloom cross-section. Right: SEM-BEI. Magnified area of the red rectangle on the Left (a) Negev-6. $\mathrm{W}_{\mathrm{CB}}$. Dense mass consisting of metallic iron $(\mathrm{Fe})$ network and interstitial areas occupied by newly formed silicate slag. The slag is composed of massive crystals fayalite (Fa), needles of celsian (Cls) and glass (Gl); (b) Negev-4. $\mathrm{M}_{\text {Св }}$. Porous mass consisting of loosely interconnected metal particles and slag restricted to intermetallic grains. The slag is heterogeneous; some areas have microlitic texture consisting of fayalite and glass; other areas are only composed of fayalite. The exterior of metal grains is composed of wustite-magnetite ex-solutions $\left(\mathrm{Wu}+\mathrm{Mt}\right.$ ). (c) Arabah-2. $\mathrm{P}_{\mathrm{CB}}-1$. Poorly sintered, highly porous mass, in which only individual metal grains (such as the one on the Right) were reduced. Slag is composed of fayalite, and unreacted quartz (Qtz). The exterior parts of reduced metallic grains are composed of wustite-magnetite ex-solutions. 
Table 4. Results of image analysis of polished sections of blooms: Quantified percent surface area of porosity and main phase components.

\begin{tabular}{|c|c|c|c|c|c|c|}
\hline \multirow{2}{*}{$\begin{array}{c}\text { Sample } \\
\text { No. }\end{array}$} & \multirow{2}{*}{$\begin{array}{l}\text { Bloom } \\
\text { Grade }\end{array}$} & \multirow{2}{*}{$\begin{array}{c}\text { Pores \% } \\
\text { Surface Area }\end{array}$} & \multicolumn{4}{|c|}{ Main Components (\% Surface Area) } \\
\hline & & & $\begin{array}{l}\text { Metallic } \\
\text { Iron }\end{array}$ & $\begin{array}{l}\text { Newly Formed } \\
\text { Fe Oxide }\end{array}$ & $\begin{array}{l}\text { Newly Formed } \\
\text { Silicate Slag }\end{array}$ & Quartz \\
\hline Negev-1 & $\mathrm{W}_{\mathrm{CB}}$ & 10 & 40 & 2 & 48 & - \\
\hline Negev-2 & $\mathrm{W}_{\mathrm{CB}}$ & 24 & 31 & 6 & 39 & - \\
\hline Negev-3 & $\mathrm{W}_{\mathrm{CB}}$ & 20 & 38 & 4 & 38 & - \\
\hline Negev-4 & $\mathrm{M}_{\mathrm{CB}}$ & 26 & 25 & 16 & 33 & - \\
\hline Negev-5 & $\mathrm{W}_{\mathrm{CB}}$ & 21 & 34 & 2 & 43 & - \\
\hline Negev-6 & $\mathrm{W}_{\mathrm{CB}}$ & 19 & 45 & 3 & 33 & - \\
\hline Negev-7 & $\mathrm{P}_{\mathrm{CB}}-1$ & 52 & 5 & 1 & 37 & 5 \\
\hline Negev-8 & $\mathrm{W}_{\mathrm{CB}}$ & 6 & 44 & 5 & 45 & - \\
\hline Negev-9 & $\mathrm{P}_{\mathrm{CB}}-2$ & 37 & 16 & 26 & 21 & - \\
\hline Ajloun-1 & $\mathrm{P}_{\mathrm{CB}}-2$ & 49 & 5 & 21 & 25 & - \\
\hline Ajloun-2 & $\mathrm{P}_{\mathrm{CB}}-2$ & 52 & 11 & 17 & 20 & - \\
\hline Ajloun-3 & $\mathrm{M}_{\mathrm{CB}}$ & 30 & 24 & 15 & 31 & - \\
\hline Arabah-1 & $\mathrm{P}_{\mathrm{CB}}-1$ & 31 & 11 & 2 & 25 & 31 \\
\hline Arabah-2 & $\mathrm{P}_{\mathrm{CB}-1}$ & 42 & 3 & 1 & 34 & 20 \\
\hline \multicolumn{2}{|c|}{ Average $(n=6) W_{C B}$} & 17 & 39 & 4 & 41 & - \\
\hline \multicolumn{2}{|c|}{ Average $(n=2) M_{C B}$} & 28 & 25 & 16 & 32 & - \\
\hline \multicolumn{2}{|c|}{ Average $(n=3) P_{C B}-1$} & 42 & 6 & 1 & 32 & 19 \\
\hline \multicolumn{2}{|c|}{ Average $(n=3) P_{C B}-2$} & 46 & 11 & 21 & 22 & - \\
\hline
\end{tabular}

$\mathrm{P}_{\mathrm{CB}}$-poorly consolidated bloom, $\mathrm{M}_{\mathrm{CB}}$-moderately consolidated bloom, $\mathrm{W}_{\mathrm{CB}}$-well-consolidated bloom.

$W_{\text {Св }}(n=6)$ show the lowest porosity with average area of $17 \%$ and the highest amount of reduced metallic iron (average of 39\%) forming a single interconnected network, with a significant amount of silicate slag filling large interstitial areas (c. 50-200 $\mu \mathrm{m}$ ) and the relatively low amount of iron oxide (Figure 6a).

$M_{C B}(n=2)$ have moderate porosity and moderate amount of reduced metal. Metal particles are only loosely interconnected with silicate slag usually restricted to intermetallic grains (Figure 6b).

$P_{C B}(n=6)$ are extremely porous, poorly sintered, and friable, with only individual grains of reduced iron, indicating poor reduction. This group can be generally divided into two types based on their slag characteristics: $P_{C B}$-type 1 , are distinguished by varying amounts of relic quartz $(5 \%-31 \%$ area), while $\mathrm{P}_{\mathrm{CB}}$-type 2 has the highest amount of non-reduced (relic) iron oxide (Figure 6c).

The relation between porosity, reduced metallic area, and the relative amount of the main phases is shown in Figure 7. Overall, from $\mathrm{W}_{\mathrm{CB}}$ to $\mathrm{P}_{\mathrm{CB}}$, the amount of reduced iron increases and the porosity decreases. The decrease in the amount of silicate slag phase and the increase of iron oxide phases from $\mathrm{W}_{\mathrm{CB}}$ to $\mathrm{P}_{\mathrm{CB}}$-type 2 indicates tendency towards incomplete ore smelting. The significant amount of silicate minerals (including newly formed minerals and unreacted quartz), and only low presence of iron oxide in $\mathrm{P}_{\mathrm{CB}}$-type 1 indicates that there was not enough iron oxide in the ore to accomplish metal reduction. 


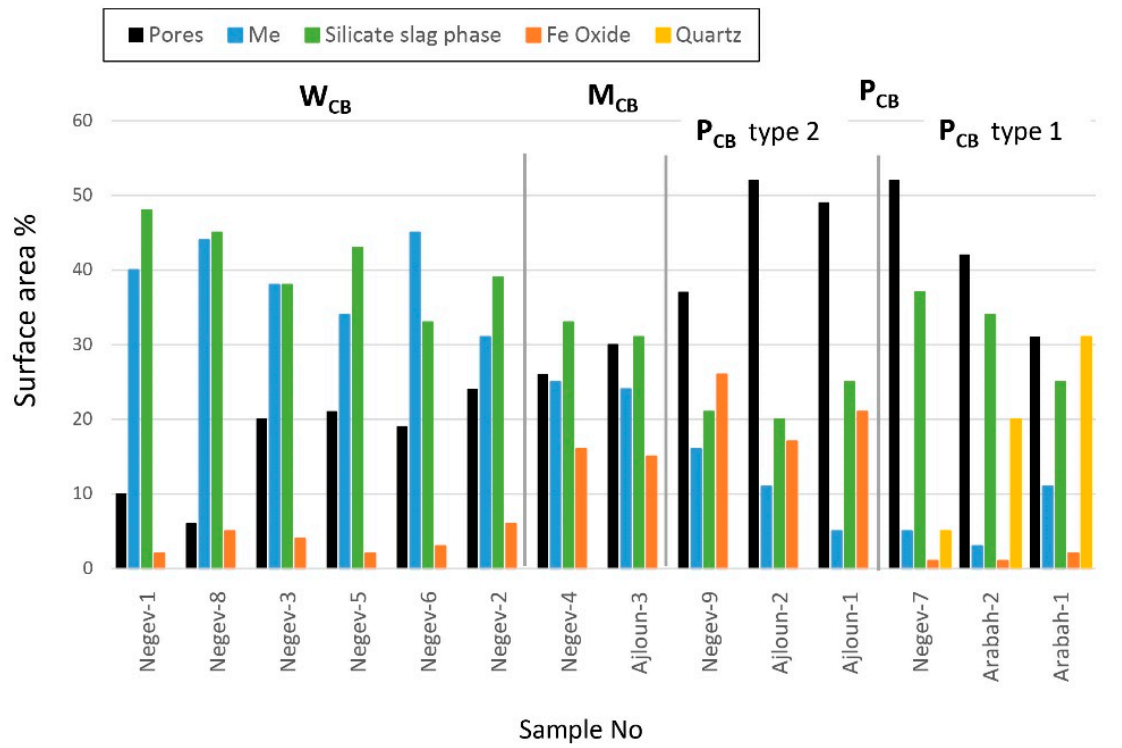

Figure 7. The correlation (\%) between porosity, reduced metallic area, newly formed silicate slag area, iron oxide area, and quartz area, according to bloom consolidation degree $\left(\mathrm{W}_{\mathrm{CB}}, \mathrm{M}_{\mathrm{CB}}, \mathrm{P}_{\mathrm{CB}}\right.$-type $1, \mathrm{P}_{\mathrm{CB}}$-type 2$)$.

\subsubsection{Chemical and Mineralogical Analysis of Slag}

Slag analysis generally shows high heterogeneity, although certain differences can be identified between the three distinguished bloom grades. Mineralogically, the slags of $\mathrm{W}_{\mathrm{CB}}, \mathrm{M}_{\mathrm{CB}}$, and $\mathrm{P}_{\mathrm{CB}}$-type 1 are composed of similar phases, while $P_{C B}$-type 2 slag show significantly different mineral and chemical composition (see below). The most common mineral phases identified in each slag sample are summarized in Table 5 (SEM-EDS analyses of the specific mineralogy are detailed in Supplementary Table S1).

Table 5. Major phase constituents of slag from assayed blooms as determined by SEM-EDS analyses.

\begin{tabular}{|c|c|c|}
\hline Sample & Grade & Major Phase Constituents \\
\hline Negev-1 & $\mathrm{W}_{\mathrm{CB}}$ & $\begin{array}{l}\text { Hedenbergite }\left(\mathrm{CaFeSi}_{2} \mathrm{O}_{6}\right) \text {, fayalite }\left(\mathrm{Fe}_{2} \mathrm{SiO}_{4}\right) \text {-kirschsteinite }\left(\mathrm{CaFeSiO}_{4}\right) \text { series, celsian } \\
\qquad\left(\mathrm{BaAl}_{2} \mathrm{Si}_{2} \mathrm{O}_{8}\right) \text {, pyrrhotite }(\mathrm{FeS})\end{array}$ \\
\hline Negev-2 & $\mathrm{W}_{\mathrm{CB}}$ & $\begin{array}{l}\text { Calico-olivine }\left(\mathrm{Ca}_{2} \mathrm{SiO}_{4}\right) \text {, melilite }\left(\mathrm{Ca}_{2}(\mathrm{Al}, \mathrm{Mg}, \mathrm{Fe})(\mathrm{Si}, \mathrm{Al})_{2} \mathrm{O}_{7}\right) \text {, kirschsteinite }\left(\mathrm{CaFeSiO}_{4}\right) \text {, } \\
\text { magnetite }\left(\mathrm{Fe}_{3} \mathrm{O}_{4}\right) \text {, wustite }(\mathrm{FeO}) \text {, pyrrhotite }(\mathrm{FeS})\end{array}$ \\
\hline Negev-3 & $\mathrm{W}_{\mathrm{CB}}$ & Hedenbergite $\left(\mathrm{CaFeSi}_{2} \mathrm{O}_{6}\right)$, fayalite $\left(\mathrm{Fe}_{2} \mathrm{SiO}_{4}\right)$, pyrrhotite $(\mathrm{FeS})$ \\
\hline Negev-4 & $\mathrm{M}_{\mathrm{CB}}$ & $\begin{array}{l}\left.\text { Hedenbergite }\left(\mathrm{CaFeSi}_{2} \mathrm{O}_{6}\right) \text {, fayalite }\left(\mathrm{Fe}_{2} \mathrm{SiO}_{4}\right) \text {-kirschsteinite }(\mathrm{CaFeSiO})_{4}\right) \text { series, rhonite } \\
\left(\mathrm{Ca}_{2}\left(\mathrm{Mg}, \mathrm{Fe}^{2+}, \mathrm{Fe}^{3+}, \mathrm{Ti}\right)_{6}(\mathrm{Si}, \mathrm{Al})_{6} \mathrm{O}_{20}\right) \text {, magnetite }\left(\mathrm{Fe}_{3} \mathrm{O}_{4}\right) \text {, wustite }(\mathrm{FeO}) \text {, pyrrhotite }(\mathrm{FeS})\end{array}$ \\
\hline Negev-5 & $\mathrm{W}_{\mathrm{CB}}$ & Fayalite $\left(\mathrm{Fe}_{2} \mathrm{SiO}_{4}\right)$, celsian $\left(\mathrm{BaAl}_{2} \mathrm{Si}_{2} \mathrm{O}_{8}\right)$, andremeyerite $\left(\mathrm{BaFe}_{2}\left(\mathrm{Si}_{2} \mathrm{O}_{7}\right)\right)$, pyrrhotite $(\mathrm{FeS})$ \\
\hline Negev-6 & $\mathrm{W}_{\mathrm{CB}}$ & Hedenbergite $\left(\mathrm{CaFeSi}_{2} \mathrm{O}_{6}\right)$, fayalite $\left(\mathrm{Fe}_{2} \mathrm{SiO}_{4}\right)$, celsian $\left(\mathrm{BaAl}_{2} \mathrm{Si}_{2} \mathrm{O}_{8}\right)$, pyrrhotite $(\mathrm{FeS})$ \\
\hline Negev-7 & $\mathrm{P}_{\mathrm{CB}}-1$ & Hedenbergite $\left(\mathrm{CaFeSi}_{2} \mathrm{O}_{6}\right)$, fayalite $\left(\mathrm{Fe}_{2} \mathrm{SiO}_{4}\right)$, quartz $\left(\mathrm{SiO}_{2}\right)$, pyrrhotite $(\mathrm{FeS})$ \\
\hline Negev-8 & $\mathrm{W}_{\mathrm{CB}}$ & $\begin{array}{c}\text { Kirschsteinite }\left(\mathrm{CaFeSiO}_{4}\right) \text {-monticellite }\left(\mathrm{MgCaSiO}_{4}\right) \text { series, melilite, rhonite, } \\
\text { pyrrhotite }(\mathrm{FeS})\end{array}$ \\
\hline Negev-9 & $P_{\mathrm{CB}}-2$ & $\begin{array}{c}\text { Calico-olivine }\left(\mathrm{Ca}_{2} \mathrm{SiO}_{4}\right) \text {, srebrodolskite }\left(\mathrm{Ca}_{2} \mathrm{Fe}_{2} \mathrm{O}_{5}\right) \text {, magnetite }\left(\mathrm{Fe}_{3} \mathrm{O}_{4}\right) \text {, wustite }(\mathrm{FeO}) \text {, } \\
\text { pyrrhotite }(\mathrm{FeS})\end{array}$ \\
\hline Ajloun-1 & $\mathrm{P}_{\mathrm{CB}-2}$ & Calico-olivine $\left(\mathrm{Ca}_{2} \mathrm{SiO}_{4}\right)$, srebrodolskite $\left(\mathrm{Ca}_{2} \mathrm{Fe}_{2} \mathrm{O}_{5}\right)$, magnetite $\left(\mathrm{Fe}_{3} \mathrm{O}_{4}\right)$, wustite $(\mathrm{FeO})$ \\
\hline Ajloun-2 & $\mathrm{P}_{\mathrm{CB}}-2$ & Calico-olivine $\left(\mathrm{Ca}_{2} \mathrm{SiO}_{4}\right)$, srebrodolskite $\left(\mathrm{Ca}_{2} \mathrm{Fe}_{2} \mathrm{O}_{5}\right)$, magnetite $\left(\mathrm{Fe}_{3} \mathrm{O}_{4}\right)$, wustite $(\mathrm{FeO})$ \\
\hline Ajloun-3 & $\mathrm{M}_{\mathrm{CB}}$ & Fayalite $\left(\mathrm{Fe}_{2} \mathrm{SiO}_{4}\right)$-forsterite $\left(\mathrm{Mg}_{2} \mathrm{SiO}_{4}\right)$ series, magnetite $\left(\mathrm{Fe}_{3} \mathrm{O}_{4}\right)$, wustite $(\mathrm{FeO})$ \\
\hline Arabah-1 & $P_{C B}-1$ & Fayalite $\left(\mathrm{Fe}_{2} \mathrm{SiO}_{4}\right)$, quartz $\left(\mathrm{SiO}_{2}\right)$ \\
\hline Arabah-2 & $P_{\mathrm{CB}}-1$ & Fayalite $\left(\mathrm{Fe}_{2} \mathrm{SiO}_{4}\right)$, quartz $\left(\mathrm{SiO}_{2}\right)$, pyrrhotite $(\mathrm{FeS})$ \\
\hline
\end{tabular}


The common silicates phases of $\mathrm{W}_{\mathrm{CB}}, \mathrm{M}_{\mathrm{CB}}$, and $\mathrm{P}_{\mathrm{CB}}$-type 1 , include glass, fayalite $\left(\mathrm{Fe}_{2} \mathrm{SiO}_{4}\right)$-forsterite $\left(\mathrm{Mg}_{2} \mathrm{SiO}_{4}\right)$-kirschsteinite $\left(\mathrm{CaFe}_{2} \mathrm{SiO}_{4}\right)$-monticellite $\left(\mathrm{MgCaSiO}_{4}\right)$ series, hedenbergite $\left(\mathrm{CaFeSi}_{2} \mathrm{O}_{6}\right)$, celsian $\left(\mathrm{BaAl}_{2} \mathrm{Si}_{2} \mathrm{O}_{8}\right)$, melilite $\left(\mathrm{Ca}_{2}(\mathrm{Al}, \mathrm{Mg}, \mathrm{Fe})(\mathrm{Si}, \mathrm{Al})_{2} \mathrm{O}_{7}\right)$, and rhonite $\left(\mathrm{Ca}_{2}\left(\mathrm{Mg}, \mathrm{Fe}^{2+}, \mathrm{Fe}^{3+}, \mathrm{Ti}\right)_{6}(\mathrm{Si}, \mathrm{Al})_{6} \mathrm{O}_{20}\right)$. The common iron oxide phases include wüstite and magnetite, while the accessory amounts of coulsonite $\left(\mathrm{Fe}_{2} \mathrm{~V}^{3+}{ }_{2} \mathrm{O}_{4}\right)$-hercynite $\left(\mathrm{Fe}_{2} \mathrm{Al}_{2} \mathrm{O}_{4}\right)$ series can be occasionally found. A non-stoichiometric form of iron sulphide, pyrrhotite (FeS), is also common.

The similar mineralogy of these slag is further reflected in their bulk chemical composition; samples have moderate $\mathrm{FeO}$ (27-42 wt.\%), moderate $\mathrm{SiO}_{2}$ (37-43 wt.\%), and elevated to moderate $\mathrm{CaO}$ (7-19 wt.\%) contents (Table 6, for the individual bulk area analyses see Supplementary Table S2). On the ternary diagrams $\mathrm{FeO}-\mathrm{CaO}-\mathrm{SiO}_{2}$ and $\mathrm{FeO}-\mathrm{Al}_{2} \mathrm{O}_{3}-\mathrm{SiO}_{2}$, slag of $\mathrm{W}_{\mathrm{CB}}$ and slag of $\mathrm{M}_{\mathrm{CB}}$ generally plot in proximate domains. The outstanding is sample Negev-2, in which melilite, calico-olivine, and kirschsteinite were formed due to the high bulk $\mathrm{CaO}$ (44 wt.\%) content of the slag (encircled by dotted lines, Figure 8a). In contrast to the first two groups, slag of $\mathrm{P}_{\mathrm{CB}}$-type 1 , whose bulk analyses incorporate quartz grains, plot closer towards the $\mathrm{SiO}_{2}$ end member (Figure 8a,b).

Table 6. Averaged bulk-area chemical analyses by SEM-EDS of slag according to bloom-consolidation degree: $W_{C B}(n=6), M_{C B}(n=2)$, and $P_{C B}$-type $1(n=3), P_{C B}$-type $2(n=3)$.

\begin{tabular}{|c|c|c|c|c|c|c|c|c|c|c|c|c|c|c|c|}
\hline \multicolumn{3}{|c|}{ Type of slag } & $\mathrm{Na}_{2} \mathrm{O}$ & $\mathrm{MgO}$ & $\mathrm{Al}_{2} \mathrm{O}_{3}$ & $\mathrm{SiO}_{2}$ & $\mathrm{P}_{2} \mathrm{O}_{5}$ & $\mathrm{SO}_{3}$ & $\mathrm{~K}_{2} \mathrm{O}$ & $\mathrm{CaO}$ & $\mathrm{TiO}_{2}$ & $\mathrm{~V}_{2} \mathrm{O}_{5}$ & $\mathrm{FeO}$ & $\mathrm{BaO}$ & Tot \\
\hline \multirow{2}{*}{\multicolumn{2}{|c|}{$\mathrm{W}_{\mathrm{CB}}(\mathrm{n}=6)$}} & $\bar{x}$ & 0.5 & 2 & 6.2 & 36.5 & 0.8 & 1.6 & 0.4 & 18.5 & 0.5 & 0.6 & 27 & 5.5 & 100 \\
\hline & & $\sigma$ & 0.3 & 1.1 & 2 & 7.9 & 0.8 & 0.9 & 0.4 & 14.4 & 0.7 & 0.3 & 8.8 & 8.3 & \\
\hline \multirow{2}{*}{\multicolumn{2}{|c|}{$\mathrm{M}_{\mathrm{CB}}(\mathrm{n}=2)$}} & $\bar{x}$ & 1.4 & 4.0 & 12.0 & 36.1 & 0.6 & 0.6 & 3.2 & 7.6 & 0.7 & bdl & 32.9 & bdl & 99.1 \\
\hline & & $\sigma$ & 0.3 & 1.5 & 0.6 & 3.7 & 0.4 & 0.4 & 2.1 & 3.2 & 0.2 & & 3.1 & & \\
\hline \multirow{4}{*}{$\begin{array}{l}\mathrm{P}_{\mathrm{CB}}-1 \\
(\mathrm{n}=3)\end{array}$} & \multirow{2}{*}{$\begin{array}{c}\text { Qtz } \\
\text { included }\end{array}$} & $\bar{x}$ & 0.2 & 0.3 & 2 & 61.2 & 0.3 & 0.6 & 0.5 & 4.7 & 0.5 & 0.2 & 28.2 & 1 & 99.7 \\
\hline & & $\sigma$ & 0.1 & 0.1 & 1.7 & 4 & 0.2 & 0.4 & 0.3 & 4.9 & 0.5 & 0.2 & 0.8 & 1.3 & \\
\hline & \multirow{2}{*}{$\begin{array}{c}\text { Qtz } \\
\text { excluded }\end{array}$} & $\bar{x}$ & 0.2 & 0.5 & 3.1 & 42.7 & 0.3 & 0.9 & 0.8 & 6.5 & 0.9 & 0.3 & 41.9 & 1.5 & 99.6 \\
\hline & & $\sigma$ & 0.1 & 0.2 & 2.6 & 4.6 & 0.2 & 0.5 & 0.4 & 5.8 & 0.9 & 0.2 & 7.9 & 2 & \\
\hline \multirow{2}{*}{\multicolumn{2}{|c|}{$\mathrm{P}_{\mathrm{CB}-2}(\mathrm{n}=3)$}} & $\bar{x}$ & bdl & 1.7 & 2.9 & 18.5 & 0.5 & 4.1 & bdl & 46 & 1.1 & bdl & 24.2 & 0.2 & 99.2 \\
\hline & & $\sigma$ & & 0.5 & 0.7 & 9.5 & 0.6 & 3.7 & & 3.3 & 1.7 & & 9.8 & 0.3 & \\
\hline
\end{tabular}

Fog $\mathrm{P}_{\mathrm{CB}}-1$, two kinds of bulk analyses represent: (1) Analyses of slag incorporating porphyritic quartz relics (Qtz included); and (2) Analyses of slag without quartz relics (Qtz excluded). Abbreviations. Tot: Total sum of oxides in a sample; bdl: beyond detection limits of the EDS.

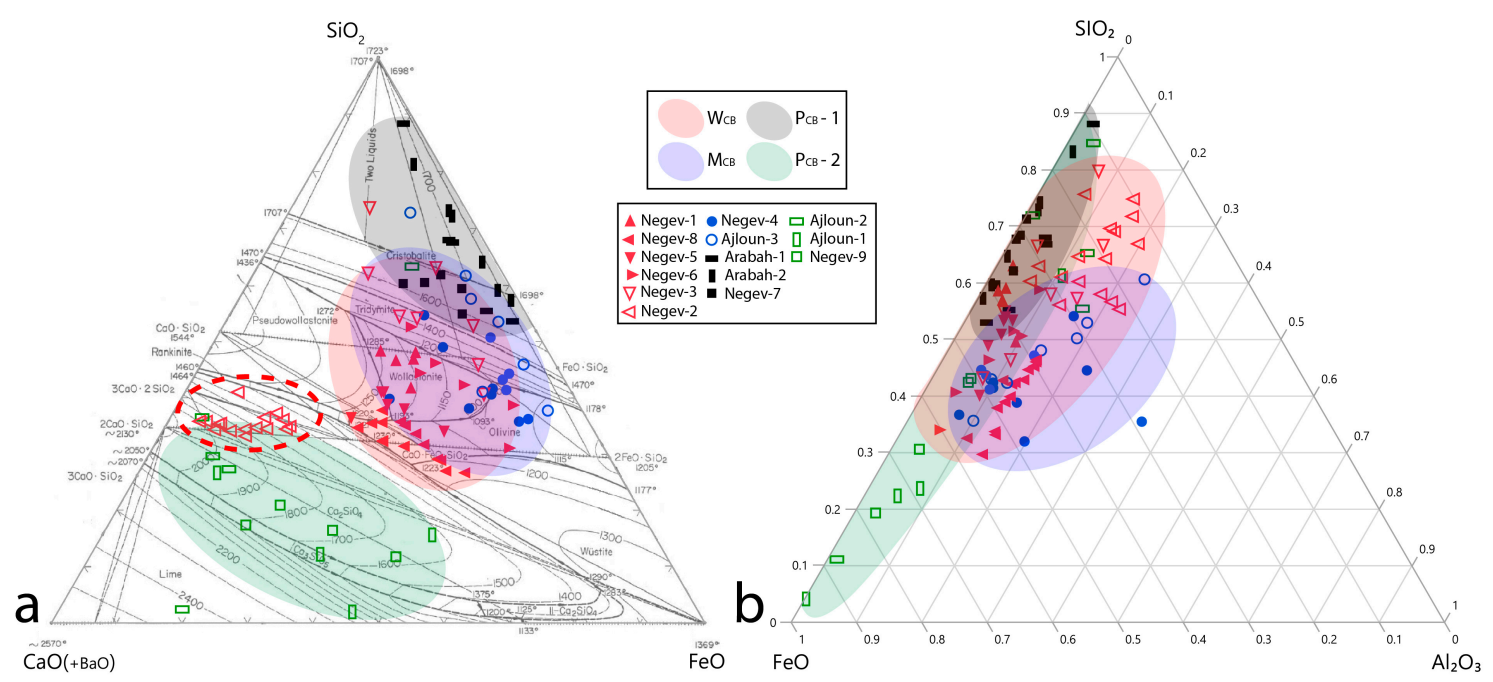

Figure 8. Bulk-area analyses of slag, as plotted on the ternary diagrams: (a) $\mathrm{CaO}(+\mathrm{BaO})-\mathrm{FeO}-\mathrm{SiO}_{2}$; with solidus lines, after Figure 586 in reference [32]; (b) $\mathrm{Al}_{2} \mathrm{O}_{3}-\mathrm{FeO}-\mathrm{SiO}_{2}$. Each dot represents one bulk-area analysis. Ellipses represent domains of all slags attributed to $\mathrm{W}_{\mathrm{CB}}$ (red), $\mathrm{M}_{\mathrm{CB}}$ (blue), $\mathrm{P}_{\mathrm{CB}}$-type 1 (grey), and $\mathrm{P}_{\mathrm{CB}}$-type 2 (green) groups. Red dotted area designates sample outlier (Negev-2) of a group $\mathrm{W}_{\mathrm{CB}}$. $\mathrm{P}_{\mathrm{CB}}$-type 1 domain represents analyses of the slag-rich areas including porphyritic quartz relics. 
Although reflecting similarities in mineralogical formation, $\mathrm{W}_{\mathrm{CB}}, \mathrm{M}_{\mathrm{CB}}$, and $\mathrm{P}_{\mathrm{CB}}$-type 1 groups, exhibit variety of micro-textures. Figures 9-11 show representative microstructures obtained for these groups. $\mathrm{W}_{\mathrm{CB}}$ slag often incorporate large primary prismatic crystals of fayalite and massive, prismatic, and twinned crystals of hedenbergite indicating relatively slow cooling rates (Figure 9a-c). Glassy matrix of $W_{C B}$ slag commonly contains dendrites of secondary olivine or hedenbergite. In Ba-rich samples (e.g., Negev-1 and Negev-5), celsian and andremeyerite typically occur as needles and dendrites, respectively. The non-stochiometric iron sulphide Pyrrhotite occurs as small spherical prills $(2-10 \mu \mathrm{m})$, as amoeboid forms (5-15 $\mu \mathrm{m}$ long), and next to metal, it forms a eutectics (Figure 9b,c). Melilite occurs both as euhedral crystals and as microlitic matrix (Figure 9d).
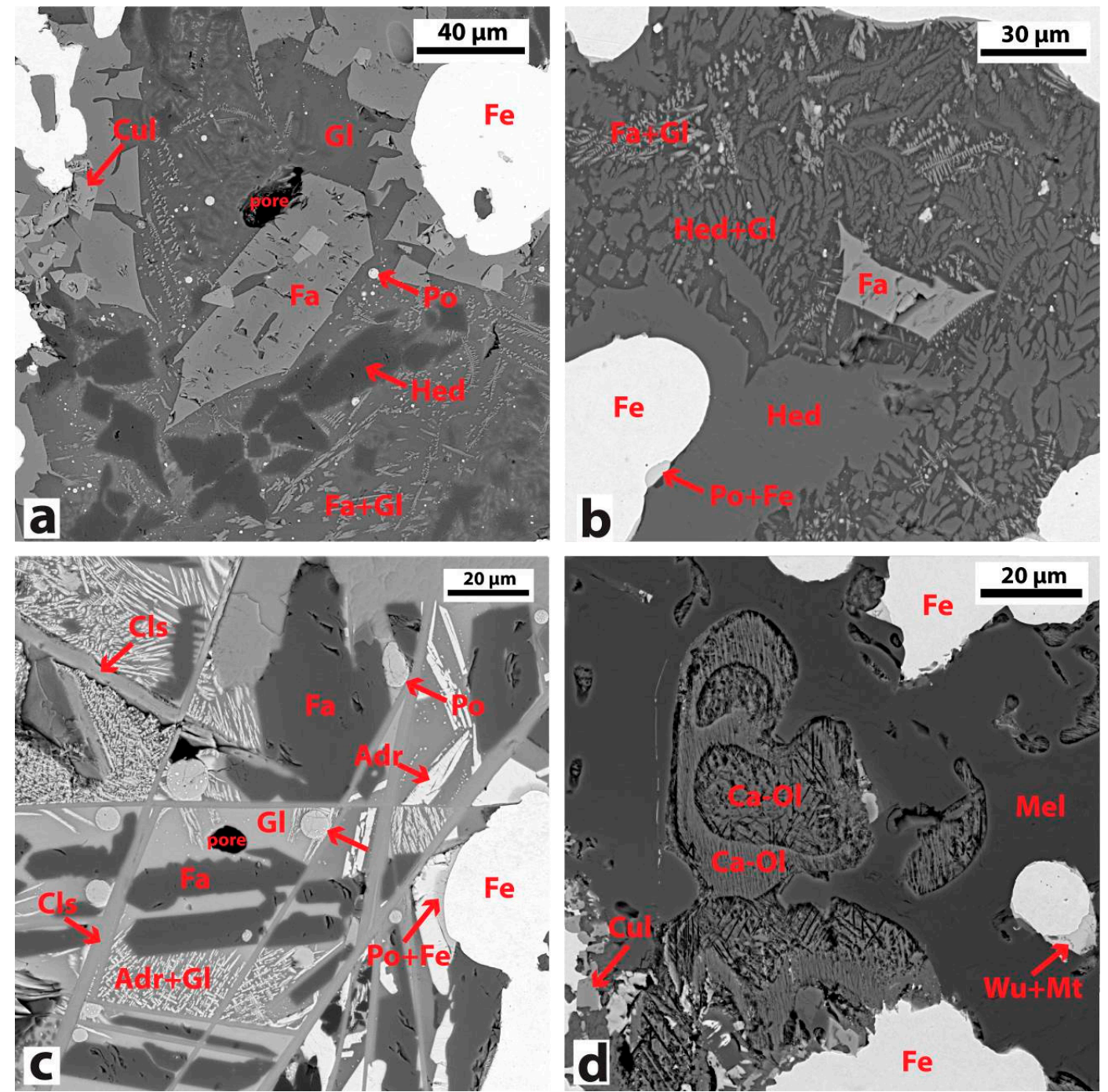

Figure 9. Typical microstructures of slag from $\mathrm{W}_{\mathrm{CB}}$. SEM-BEI. (a) Negev-6. Slag composed of large prismatic crystals of fayalite (Fa), large twinned hedenbergite (Hed), coulsonite (Cul), prills of pyrrhotite (Po) in a matrix of glass (Gl), and fayalite microlites; (b) Negev-3. Slag composed of euhedral crystal of fayalite, massive crystals of hedenbergite in a microlitic matrix of glass, hedenbergite, and fayalite. Pyrrhotite-metal eutectics (Po+Fe) is locally present; (c) Negev-5. Slag composed of large euhedral crystals of fayalite, needles of celsian (Cls) grown through fayalite with shear deformation, laths and dendrites of andremeyerite (Adr), prills of pyrrhotite, and localized pyrrhotite-metal eutectics; (d). Negev-2. Twinned calico-olivine (Ca-Ol), euhedral coulsonite in a microlitic matrix of melilite (Mel). Wusite-magnetite ex-solutions are locally present. 


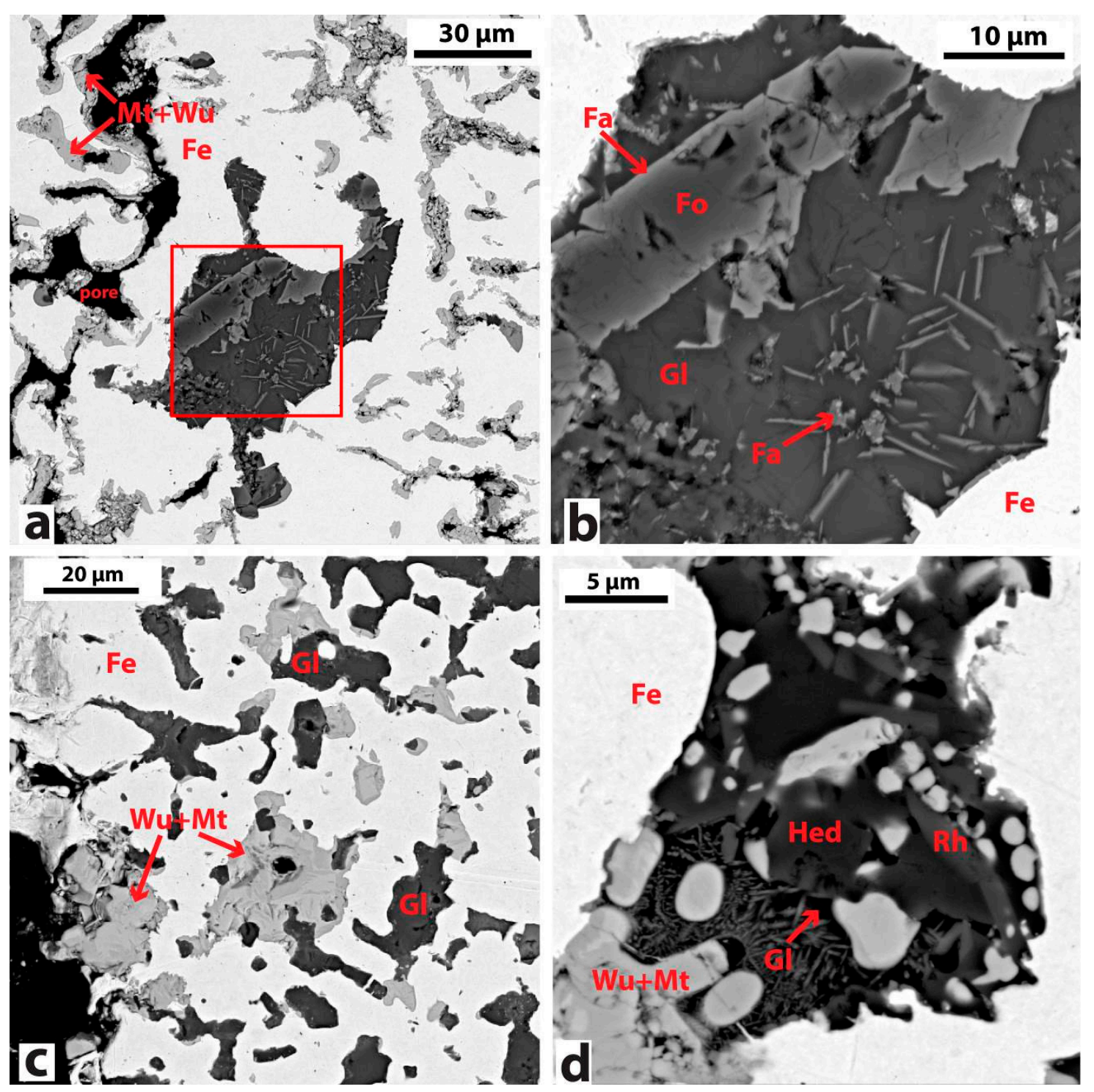

Figure 10. Typical microstructures of slag from $\mathrm{M}_{\mathrm{CB}}$. SEM-BEI. Ajloun-3 (a,b): (a) Intermetallic grain area occupied by medium-sized $(50 \mu \mathrm{m})$ inclusion of silicate slag. Elongated inclusions of magnetite-wustite $(\mathrm{Mt}+\mathrm{Wu})$ ex-solutions occur at the boundaries of metal grains $(\mathrm{Fe}) ;(\mathbf{b})$ magnified area of a red rectangle from $a$. Primary prismatic crystals of forsterite (Fo, core)-fayalite (Fa, exterior) series, in the glassy matrix incorporating secondary fayalite microlites. Negev-4 (c,d): (c) Highly heterogeneous area of the metal sample. Contains inclusion of microlitic glass and inclusions composed of wustite-magnetite ex-solutions; (d) Small slag area composed of ahnedral crystals of hedenbergite (Hed), small prismatic crystals of rhonite $(\mathrm{Rh})$, and microlitic glassy matrix. Wustite-magnetite ex-solutions are present at the metal-slag periphery and within silicate slag. 


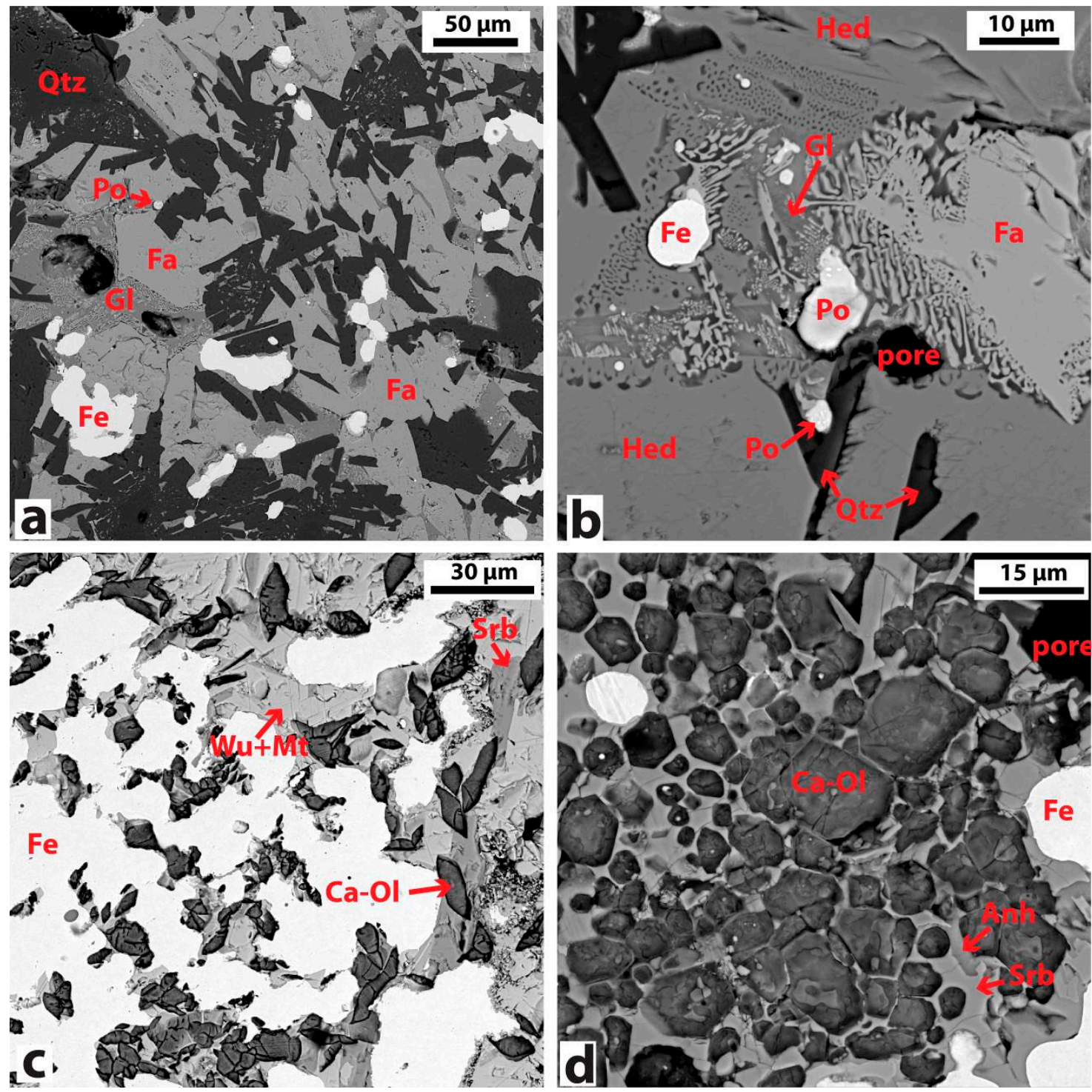

Figure 11. Typical microstructures of slag from $P_{C B}$. SEM-BEI. $P_{C B}$ type $1(\mathbf{a}, \mathbf{b})$ : (a) Arabah-2. Porphyritic grains of quartz (Qtz), large prismatic crystals of fayalite $(\mathrm{Fa})$, prills of pyrrhotite $(\mathrm{Po})$ in a microlitic glassy (Gl) matrix; (b) Negev-7. Tabular crystals of quarts, large crystals of hendenbergite (Hed), euhedral crystal of fayalite, which peripherally formed ex-solution texture with residual slag melt (glass); $P_{C B}$ type 2 (c,d): (c) Ajloun-2. Area of reduced metal (Fe) and slag. The slag is composed of rhomboid crystals of calico-olivine ( $\mathrm{Ca}-\mathrm{Ol})$, elongated crystals of srebrodolskite $(\mathrm{Srb})$, and magnetite-wustite ex-solution (Mt-Wu); (d) Negev-9. Slag composed of subhedral calico-olivine, finely resolved srebrodolskite, and localized anhydrite (Anh).

In contrast, $\mathrm{M}_{\mathrm{CB}}$ slag exhibit poorly developed morphologies, and are typically characterized by microlitic textures, featuring anhedral crystals of olivine, hedenbergite, and rhonite. These textures are probably due to the limited volume of slag characteristic of this group (Figure 10a-d). Ex-solutions of wüstite and magnetite are common in $\mathrm{M}_{\mathrm{CB}}$ slag, with magnetite incorporating 2-3 wt.\% of $\mathrm{Al}$ (Figure 10c,d). Slag of $\mathrm{P}_{\mathrm{CB}}$-type 1 are characterized by the presence of porphyritic grains of reclic quartz (up to $200 \mu \mathrm{m}$ ), prismatic crystals of fayalite, and glassy matrix (Figure 11a,b).

The $\mathrm{P}_{\mathrm{CB}}$-type 2 slag are characterized by a significantly different mineral and chemical composition, which stands in contrast to the rest of the groups (Figure 11 and Table 6). The common mineral assemblage includes calico-olivine (larnite, $\left.\mathrm{Ca}_{2} \mathrm{SiO}_{4}\right)$, srebrodolskite $\left(\mathrm{Ca}_{2} \mathrm{Fe}^{3+}{ }_{2} \mathrm{O}_{5}\right)$ as well as wüstite and magnetite (Table 5). This can be explained by the relatively high bulk content of $\mathrm{CaO}(46 \mathrm{wt} . \%)$, 
low $\mathrm{SiO}_{2}(19 \mathrm{wt} . \%)$, and moderate $\mathrm{FeO}(24 \mathrm{wt} . \%)$ content. Slag analyzed from this group significantly outlay from the rest on the ternary diagram towards the end member of $\mathrm{CaO}$ (Figure 8a).

The micro-textures of this slag group reveal extreme heterogeneity, especially regarding the distribution of calico-olivine and iron oxides. Calico-olivine is present in the form of euhedral or slightly rounded crystals, displaying cross or parallel twinning, srebrodolskite occurs as finely crystalline matrix or as elongated crystals, and magnetite and wüstite form ex-solution textures similar to the $\mathrm{M}_{\mathrm{CB}}$ slag (Figure 11c,d)

\subsubsection{Effect of Sulphur and Copper on Iron}

Apart from consolidation degree, another significant parameter affecting use of the ore is the presence of harmful impurities, such as sulphur. This element was found in particularly high concentrations in some Negev ores (up to $5.1 \mathrm{wt} . \% \mathrm{~S}$, based on SEM-EDS analyses of metal-rich areas, $500 \times 500 \mu^{2}$ ). The negative impact of sulphur on the metal is associated with the formation of iron sulphide-metal eutectics, which melts during temperatures of hot forging of iron (at $988^{\circ} \mathrm{C}$ ) causing brittleness of the metal [33] (p. 39). By modern metallurgy standards, steel with sulphur levels higher than $0.03 \mathrm{wt} . \%$ is considered too brittle for most purposes, while in the past, iron with sulphur levels up to 1.1-1.5 wt.\% was sometimes used in the manufacture of various objects [9] (p. 21), [34]. Only two out of the nine samples of Negev blooms reveal sulphur levels higher than $0.5 \mathrm{wt} . \%$ indicating a poor-quality metal.

Apart from sulphur, high levels of copper, up to $1.2 \mathrm{wt} . \%$, were detected in the metal islands of the Arabah-2 sample (Timna deposit), while several pyrrhotite prills of Arabah-2 sample were found to contain 23-29 wt.\% of $\mathrm{Cu}$. The presence of copper, first noticed in the analysis of the ore (Figure 3f), is not surprising, as the hematite nodules tested in this study are closely associated with the copper mineralization at Timna geological formations. Similarly to sulphur, copper causes hot-shortness of iron, which could have been pronounced at the measured Cu levels [33] (p. 43). The presence of copper impurity, along with poor reducibility of the Timna ore, therefore suggests unlikelihood that the Timna samples could have been used in a bloomery furnace.

\section{Discussion}

Results of the assaying method show that some of the utilized/tested ores produced well consolidated blooms. Although similar results may not be fully reproducible in a bloomery furnace, they allow reflections on some necessary parameters that if implemented, may permit successful smelting of these ores in a bloomery furnace. Due to the limited archaeological evidence for iron ore exploitation and the presence and availability of some quality ore deposits in the southern Levant, the results of this study are significant for understanding the emergence and development of early iron production in the region.

Prior to discussing the results of the crucible assaying experiments, it is important to highlight the similarities and the inherited differences of the method to bloomery smelting. In both methods, the final product is a bloom formed by coalescence of solid metal particles. The effect of coalescence is particularly evidenced from the $\mathrm{W}_{\mathrm{CB}}$ group (see below), in which metal forms a tightly interconnected network. Further, similarly to the ancient bloom, lies the fact that the metal is richly penetrated by slag.

A major difference between the two methods lies in the fact that consolidation of reduced metal is not assisted by gravity, nor by the convection of hot air. Moreover, slag is not separated from metal through tapping. These specifics affected different mechanism of iron and slag formation, resulting in different slag mineralogy. However, the non-evacuation of slag in the crucible assaying system can be paralleled with smelting in a bowl furnace operated without tapping [35].

The differences in the slag mineral assemblages can be clearly inferred from the present study. Generally, the slag obtained in the assaying non-tapping system is predominated by hedenbergite-fayalite assemblages, whereas slag from the tapping bloomery system results in fast cooling and non-equilibrium conditions, under which fayalite-kirschsteinite solid solutions usually 
form [36,37] (p. 197), [38] (pp: 68-76). Furthermore, slag of the present experiments, at least in the case of $\mathrm{W}_{\mathrm{CB}}$, show very low $\mathrm{FeO}$ contents $(\mathrm{FeO}=27 \mathrm{wt} . \%)$, while typical bloomery slag has $\mathrm{FeO} 50-75 \mathrm{wt} . \%$ [10]. This, along with a very high percentage of metal reduced from the ore in the experiments (i.e., the estimated yield of $W_{C B}$ is $c .>70$ mass $\%$ ), suggests a highly reducing atmosphere, far surpassing that of a typical bloomery furnace, generally resulting in a much lower yield (avg. metal yield is $30-50$ mass \%, [39]). However, it is possible that smelting with a lower charcoal to ore ratio would have potentially promoted lower reducing conditions and higher $\mathrm{FeO}$ contents in the slag, resulting in different amounts of reduced metal and different degrees of consolidation.

Another parameter strongly affecting the results of the assaying experiments is the limited amount of ore used. In each experiment, $20 \mathrm{~g}$ of ore were used, homogenized from an initial 40-80 g sample. Nevertheless, this cannot compensate for the natural variability within a given ore body and is, therefore, not sufficiently representative. In contrast, several $\mathrm{kg}$ of ore is usually used in a bloomery furnace, allowing for a better homogeneity of the ore composition.

Despite the abovementioned complications, the assaying experiments allowed to produce some conclusions regarding the feasibility of the tested ores for smelting in a bloomery shaft furnace. Out of the 14 ore samples incorporated in the study, six were smelted into well consolidated blooms (categorised as $\mathrm{W}_{\mathrm{CB}}$ ), two were moderately consolidated $\left(\mathrm{M}_{\mathrm{CB}}\right)$, and six were poorly consolidated blooms $\left(\mathrm{P}_{\mathrm{CB}}\right)$. The $\mathrm{P}_{\mathrm{CB}}$ group was further divided, based on chemical and mineralogical composition, into two types; $\mathrm{P}_{\mathrm{CB}}$-type 1 and $\mathrm{P}_{\mathrm{CB}}$-type 2. Generally, ores utilized to produce these bloom types did not provide sufficient amount of specific lithophile elements in the gangue to enable the formation of fluid slag.

Ores that produced $\mathrm{P}_{\mathrm{CB}}$-type 1 blooms have low $\mathrm{FeO}$ contents in the range of $43-54 \mathrm{wt} . \%$, high silica contents of 30-38 wt.\%, and relatively low contents of $\mathrm{CaO}$ and $\mathrm{Al}_{2} \mathrm{O}_{3}$. The poor outcome of smelting such ores is evidenced by the low quantity of reduced iron metal and excess of quartz, indicating high viscosity of resultant slag. Bloomery smelting of these ores would likely have a similar outcome, converting all iron oxide into slag minerals (such as fayalite) and zero to low metal yield, as suggested by [8] (p. 93).

However, altering the composition of the bloomery slag, by using the correct flux additives, such as calcium rich minerals, with some amounts of alumina and magnesium may potentially allow smelting of non-sufficiently rich iron ores through the formation of low viscosity slag characterized by low $\mathrm{FeO}$ contents. Such additives would bind with silica in the ore to form minerals which, similarly to fayalite, can have relatively low melting temperature and viscosity; such as kirschsteinite $\left(\mathrm{CaFeSiO}_{4}\right)$ and the melilite group. Although endmembers of the melilite group, akermanite $\left(\mathrm{Ca}_{2} \mathrm{MgSi}_{2} \mathrm{O}_{7}\right)$ and gehlenite $\left(\mathrm{Ca}_{2} \mathrm{Al}_{2} \mathrm{O}_{7}\right)$, have relatively high melting points $\left(>1400{ }^{\circ} \mathrm{C}\right)$, the incorporation of iron into melilite significantly lowers its melting point and Fe-bearing melilites are reported as dominant minerals in some bloomery iron slags [40-43].

$\mathrm{P}_{\mathrm{CB}}$-type 1 group consists of hematite-rich sandstones from Wadi Amram and Timna in the Arabah Valley, both regions well famous for copper mining in antiquity [44,45], and one sample from the Negev ores. Although only two samples of Arabah ores were tested, the possibility for bloomery exploitation of these ores seems rather unlikely. Nevertheless, the possibility of smelting these ores using mineral additives deserves further investigation.

Three ore samples resulted in blooms categorized as $\mathrm{P}_{\mathrm{CB}}$-type 2, generally have too high $\mathrm{CaO}$ content (6-16 wt.\%) versus too low $\mathrm{SiO}_{2}$ content $(2 \mathrm{wt} . \%)$ and are characterized by a ratio of $\mathrm{CaO} / \mathrm{SiO}_{2}$ $>$ 3.7. In the cases of ore samples Ajloun-1 and Negev-9, the iron oxide content is rather moderate ( $<57$ wt. \%), while the ore Ajloun-2 is extremely iron rich FeO (86 wt.\%).

Ores of such composition are difficult to smelt by the assaying method, as evidenced in the significant amount of unreacted iron ore in the produced bloom. These difficulties may be due to the high viscosity of the resultant slag. Bulk analyses of slag from $\mathrm{P}_{\mathrm{CB}}$-type 2 blooms plot in the high temperature domain $\left(1600-2000{ }^{\circ} \mathrm{C}\right)$ of the ternary diagram $\mathrm{FeO}-\mathrm{CaO}-\mathrm{SiO}_{2}$, thus corresponding to $\mathrm{Ca}_{2} \mathrm{SiO}_{4}$ and $\mathrm{Ca}_{3} \mathrm{SiO}_{5}$ (Figure 8a). The presence of calico-olivine and srebrodolskite in such slag further 
supports this hypothesis, as these minerals are uncommon in most bloomery slags and instead are often found in modern slag formed under oxidizing conditions and temperatures often higher than $1300{ }^{\circ} \mathrm{C}[46]$ (p. 3), [47].

Among the ores resulted in $\mathrm{P}_{\mathrm{CB}}$-type 2 blooms are two samples of Ajloun ores. These ores, as revealed in the comprehensive study of Mugharet el-Wardeh deposit, are often characterized by high $\mathrm{CaO}$ contents (10-30 wt.\%) and an extremely high $\mathrm{CaO} / \mathrm{SiO}_{2}$ ratio (mostly in the range of 3-10) [24] (p. 48, Table 1). Such chemical composition may be hard to smelt in a bloomery furnace. Indeed, archaeological evidence of vitreous slag with high $\mathrm{SiO}_{2}(46 \mathrm{wt} . \%)$ and $\mathrm{CaO}(20 \mathrm{wt} . \%)$ comes from the site of Tell Hammeh, situated near the Mugharet el-Wardeh deposit in the Ajloun area. Analysis of these slags indirectly supports difficulties for bloomery smelting of local ores and indicates that the ancient smelters attempted to improve the viscosity of the slag using fluxes or residues from gangue processing [5].

Another possible way to improve slag viscosity would be to increase the amount of iron entering the slag, either by deliberately selecting highly enriched iron ores and low gangue content, or by running the furnace under moderately reducing conditions to promote formation of wustite and/or magnetite. Slags rich in wüstite and magnetite with high $\mathrm{FeO}$ content were recorded from various archaeological sites exploiting the Ajloun ores [24] (pp: 51-54), Figures 67, 68, and 70 in Reference [48].

The significance of low-viscosity slag for successful reduction and consolidation of bloom is highlighted by the analysis of the well-consolidated blooms $\left(\mathrm{W}_{\mathrm{CB}}\right)$ obtained in the present experiments. All ores of the $\mathrm{W}_{\mathrm{CB}}$ group originated from various locations within the northern Negev, Israel: Wadi Nekarot, Wadi Nekarot-Evos, Eshet, and Zavar. The chemical and mineralogical composition of these ores, characterized by $\mathrm{FeO}$ in the range of $68-80 \mathrm{wt} . \%$ and a $\mathrm{CaO} / \mathrm{SiO}_{2}$ ratio lower than 2, is "well-balanced" for the crucible assaying system. Smelting of these ores allowed the formation of a sufficient amount of fluid slag, incorporating, depending on the sample, phases such as fayalite, hedenbergite, melilite, kirschsteinite, Ba-phases, and Ca- and Ba-rich glass. The low viscosity of this slag is further supported from the ternary diagram, as analyses plot in the low-temperature domain of $1100-1300{ }^{\circ} \mathrm{C}$ (Figure 8a). Hence, the fluid slag acts as liquid media favouring sintering of the solid metal particles, both in the assaying system and in the bloomery furnace [9] (p. 94). However, the sintering of metallic iron is significantly accelerated in a bloomery shaft furnace, mainly due to the downward gravitational movement of the ore and charcoal along the shaft.

Indeed, recent smelting experiments conducted in a bloomery shaft furnace, using some of these ores (samples Negev 1, Negev 3, Negev 6 mixed with Negev 7) were extremely successful, proving the feasibility for use of these specific ores for ancient iron production [49].

Moderately consolidated blooms, $\mathrm{M}_{\mathrm{CB}}$ (Negev-4 and Ajloun-3), resulted in significant amounts of iron oxide and only moderate amounts of poorly sintered metal particles. This is apparently due to the high content of 78 and $88 \mathrm{wt} . \% \mathrm{FeO}$ and only low content of non-metallic elements. Smelting of such ores in a crucible limited the amount of fluid slag phase, therefore restraining the reduced iron particles from sintering into a bloom. In contrast, the smelting of such ores in a bloomery furnace under fairly modest temperatures and moderately reducing conditions, would have converted more iron oxide of the ore into wüstite, therefore contributing to the increase of volume of fluid slag and favouring the consolidation of reduced iron particles into a bloom.

Overall, the undertaken study allows to reconsider the definition of a "good ore", in the context of direct iron reduction. Such ore is more than a rock with a significant amount of iron mineral, but rather a resource characterized by the right balance between a sufficient amount of iron mineral and lithophile elements.

\section{Conclusions}

Assaying of iron ores under laboratory conditions, combined with chemical and mineralogical analyses of the ores and their smelting products, has provided information about smelting behaviour of the ores and the properties of the produced slag. The advantage of assaying lays in the fact that it allows 
to keep constant a range of experimental parameters, isolating chemical and mineralogical composition of an ore as the only variable. This permits a relative comparison between different ores and their smelting products providing an initial indication about suitability of the ores for a bloomery smelting. Although, the extrapolation of the results of crucible assaying to bloomery smelting requires caution, it may serve to highlight the parameters required for successful bloomery smelting of these ores.

The undertaken experiments strongly demonstrate the necessity of a 'correct chemical balance' in the smelting system, in order to allow the formation of a fluid slag, and thus favour the reduction and bloom consolidation. Such balance can be natural property of the ore, or it can be achieved through the use of specific mineral additions, and/or ore beneficiation procedures, which could have been integrated into the ore smelting practices in the past.

The testing of ores from several deposits of the Southern Levant allowed to reveal potentially suitable ores for bloomery smelting. Ongoing bloomery smelting experiments using these ores combined with future provenance studies allow one to answer whether these ores were indeed exploited in antiquity.

Supplementary Materials: The following are available online at http://www.mdpi.com/2075-163X/10/1/33/s1, Figure S1: XRD analysis of the ore sample Negev-1, Figure S2: XRD analysis of the ore sample Negev-2, Figure S3: XRD analysis of the ore sample Negev-3, Figure S4: XRD analysis of the ore sample Negev-4, Figure S5: XRD analysis of the ore sample Negev-5, Figure S6: XRD analysis of the ore sample Negev-6, Figure S7: XRD analysis of the ore sample Negev-7, Figure S8: XRD analysis of the ore sample Negev-8, Figure S9: XRD analysis of the ore sample Negev-9, Figure S10: XRD analysis of the ore sample Arabah-1, Figure S11: XRD analysis of the ore sample Arabah-2, Figure S12: XRD analysis of the ore sample Ajloun-1, Figure S13: XRD analysis of the ore sample Ajloun-3, Figure S14: FTIR analysis of the ore sample Negev-1, Figure S15: FTIR analysis of the ore sample Negev-2, Figure S16: FTIR analysis of the ore sample Negev-3, Figure S17: FTIR analysis of the ore sample Negev-4, Figure S18: FTIR analysis of the ore sample Negev-5, Figure S19: FTIR analysis of the ore sample Negev-6, Figure S20: FTIR analysis of the ore sample Negev-7, Figure S21: FTIR analysis of the ore sample Negev-8, Figure S22: FTIR analysis of the ore sample Negev-9, Figure S23: FTIR analysis of the ore sample Arabah-1, Figure S24: FTIR analysis of the ore sample Arabah-2, Figure S25: FTIR analysis of the ore sample Ajloun-1, Figure S26: FTIR analysis of the ore sample Ajloun-2, Figure S27: FTIR analysis of the ore sample Ajloun-3, Figure S28: Optical microscopy structure of the ore sample Negev-1, Figure S29: Optical microscopy structure of the ore sample Negev-2, Figure S30: Optical microscopy structure of the ore sample Negev-3, Figure S31: Optical microscopy structure of the ore sample Negev-4, Figure S32: Optical microscopy structure of the ore sample Negev-5, Figure S33: Optical microscopy structure of the ore sample Negev-6, Figure S34: Optical microscopy structure of the ore sample Negev-7, Figure S35: Optical microscopy structure of the ore sample Negev-8, Figure S36: Optical microscopy structure of the ore sample Negev-9, Figure S37: Optical microscopy structure of the ore sample Arabah-1, Figure S38: Optical microscopy structure of the ore sample Arabah-2, Figure S39: Optical microscopy structure of the ore sample Ajloun-1, Figure S40: Optical microscopy structure of the ore sample Ajloun-2, Figure S41: Optical microscopy structure of the ore sample Ajloun-3, Table S1: Analyses of individual slag minerals by SEM-EDS, Table S2: Analyses of individual bulk areas of slag by SEM-EDS.

Author Contributions: Conceptualization, I.S. and A.E.-B.; methodology, I.S., A.E.-B., and K.B.; software, I.S.; validation, A.E.-B. and K.B.; formal analysis, I.S.; investigation, I.S.; resources, I.S., A.E.-B., and K.B.; data curation, I.S.; writing - original draft preparation, I.S.; writing-review and editing, A.E.-B. and K.B.; visualization, I.S.; supervision, A.E.-B.; project administration, A.E.-B.; funding acquisition, A.E.-B. and K.B. All authors have read and agreed to the published version of the manuscript.

Funding: This research was funded by Israel Science Foundation, ISF grant number 1047/17 to A.E.B., and by Ariel University collaboration grant to A.E.-B. and K.B. Postdoc fellowship to I.S. is partially supported by the ISF funding and Ariel University.

Acknowledgments: Authors wish to express their gratitude to Michael Korpushenko and Or Rahumi for assistance with the use of muffle furnaces, Natali Litvak for help with SEM analyses and Alexey Kossenko for assistance with XRD analyses. The authors are also grateful to Lee Sauder and Jake Keen for fruitful discussions and advice regarding various aspects of the assaying method and to Vanessa Workman for corrections of English and editing. Authors also would like to thank anonymous reviewers for valuable comments that significantly improved the study.

Conflicts of Interest: The authors declare no conflict of interest. The funders had no role in the design of the study; in the collection, analyses, or interpretation of data; in the writing of the manuscript, or in the decision to publish the results. 


\section{References}

1. Eliyahu-Behar, A.; Yahalom-Mack, N.; Shilstein, S.; Zukerman, A.; Shafer-Elliott, C.; Maeir, A.M.; Boaretto, E.; Finkelstein, I.; Weiner, S. Iron and bronze production in Iron Age IIA Philistia: New evidence from Tell es-Safi/Gath, Israel. J. Archaeol. Sci. 2012, 39, 255-267. [CrossRef]

2. Eliyahu-Behar, A.; Yahalom-Mack, N.; Gadot, Y.; Finkelstein, I. Iron smelting and smithing in major urban centers in Israel during the Iron Age. J. Archaeol. Sci. 2013, 40, 4319-4330. [CrossRef]

3. Erb-Satullo, N.L.; Walton, J.T. Iron and copper production at Iron Age Ashkelon: Implications for the organization of Levantine metal production. J. Archaeol. Sci. Rep. 2017, 15, 8-19. [CrossRef]

4. Erb-Satullo, N.L. The Innovation and Adoption of Iron in the Ancient Near East. J. Archaeol. Res. 2019, 27, 557-560. [CrossRef]

5. Veldhuijzen, H.A.; Rehren, T. Slags and the city: Early iron production at Tell Hammeh, Jordan, and Tel Beth-Shemesh, Israel. In Metals and Mines: Studies in Archaeometallurgy; La Niece, S., Hook, D.R., Craddock, P., Eds.; Archetype, British Museum: London, UK, 2007; pp. 189-201. ISBN 9781904982197.

6. Oliver, R.A.; Oliver, R.; Fagan, B.M. Africa in the Iron Age: C. 500 BC-1400 AD; Cambridge University Press: Cambridge, UK, 1975; ISBN 978-0521099004.

7. Pleiner, R. Iron in Archaeology: The European Bloomery Smelters; Archeologický Ustav AV ČR: Prague, Czech Republic, 2000; ISBN 8086124266.

8. Buchwald, V.F. Iron and Steel in Ancient Times; Kgl. Danske Videnskabernes Selskab: Copenhagen, Denmark, 2005; ISBN 978-8773043080.

9. Rostoker, W.; Bronson, B. Pre-Industrial Iron: Its Technology and Ethnology; Archeomaterials: Filadelphia, PA, USA, 1990; ISBN 9780924171031.

10. Rehren, T.; Charlton, M.; Chirikure, S.; Humphris, J.; Ige, A.; Veldhuijzen, H.A. Decisions set in slag: The human factor in African iron smelting. In Metals and Mines: Studies in Archaeometallurgy; La Niece, S., Hook, D.R., Craddock, P., Eds.; Archetype, British Museum: London, UK, 2007; pp. 211-218. ISBN 9781904982197.

11. Iles, L.; Martinón-Torres, M. Pastoralist iron production on the Laikipia Plateau, Kenya: Wider implications for archaeometallurgical studies. J. Archaeol. Sci. 2009, 36, 2314-2326. [CrossRef]

12. Killick, D.; Miller, D. Smelting of magnetite and magnetite-ilmenite iron ores in the northern Lowveld, South Africa, ca. 1000 CE to ca. 1880 CE. J. Archaeol. Sci. 2014, 43, 239-255. [CrossRef]

13. Blakelock, E.; Martinon-Torres, M.; Veldhuijzen, H.A.; Young, T. Slag inclusions in iron objects and the quest for provenance: An experiment and a case study. J. Archaeol. Sci. 2009, 36, 1745-1757. [CrossRef]

14. Charlton, M.; Humphris, J. Exploring ironmaking practices at Meroe, Sudan-A comparative analysis of archaeological and experimental data. Archaeol. Anthropol. Sci. 2019, 11, 895-912. [CrossRef]

15. Senn, M.; Gfeller, U.; Guénette-Beck, B.; Lienemann, P.; Ulrich, A. Tools to qualify experiments with bloomery furnaces. Archaeometry 2010, 52, 131-145. [CrossRef]

16. Thiele, A.; Dévényi, L. Modelling possibilities of the medieval bloomery process under laboratory conditions. Mater. Sci. Forum 2013, 729, 290-295. [CrossRef]

17. Martinón-Torres, M.; Rehren, T. Alchemy, chemistry and metallurgy in Renaissance Europe: A wider context for fire-assay remains. Hist. Metall. 2015, 39, 14-28.

18. Killick, D. Invention and innovation in African iron-smelting technologies. Camb. Archaeol. J. 2015, 25, 307-319. [CrossRef]

19. Agricola, G. De Re Metallica; Hoover, H.C.; Hoover, L.H., Translators; Dover Publications: New York, NY, USA, 1950; ISBN 9780486600062.

20. Ploquin, A.; Orzechowski, S.; Briand, B. Paléométallurgie à Mleiha: Une première approche. Travaux de la Maison de l'Orient méditerranéen. In Mleiha I. Environnement, Stratégies de subsistance et artisanats; Mouton, M., Ed.; Maison de l'Orient méditerranéen: Lyon, France, 1999; pp. 171-190. ISBN 2-903264-71-6.

21. Stepanov, I. Ferrous Metal Production and Use at Saruq al-Hadid. Ph.D. Thesis, University of New England, Armidale, Australia, 2019.

22. Kassianidou, V. Could Iron Have Been Produced in Cyprus? Department of Antiquities: Nicosia, Cyprus, 1994; pp. 73-81. 
23. Ilani, S.; Rosenthal, E.; Kronfeld, J.; Flexer, A. Epigenetic dolomitization and iron mineralization along faults and their possible relation to the paleohydrology of southern Israel. Appl. Geochem. 1988, 3, 487-498. [CrossRef]

24. Al-Amri, Y.A.S. The Role of The Iron Ore Deposit of Mugharet El-Wardeh/Jordan in the Development of the Use of Iron in Southern Bilad El-Sham. Ph.D. Thesis, Bochum University, Bochum, Germany, 2008.

25. Erel, Y.; Listovsky, N.; Matthews, A.; Ilani, S.; Avni, Y. Tracing end-member fluid sources in sub-surface iron mineralization and dolomitization along a proximal fault to the dead sea transform. Geochim. Cosmochim. Acta 2006, 70, 5552-5570. [CrossRef]

26. Grosz, S.; Matthews, A.; Ilani, S.; Ayalon, A.; Garfunkel, Z. Iron mineralization and dolomitization in the Paran Fault zone, Israel: Implications for low-temperature basinal fluid processes near the Dead Sea Transform. Geofluids 2006, 6, 137-153. [CrossRef]

27. Dill, H.G.; Botz, R.; Berner, Z.; Abdullah, M.; Hamad, A. The Origin of Pre-and Synrift, Hypogene Fe-P Mineralization during the Cenozoic along the Dead Sea Transform Fault, Northwest Jordan. Econ. Geol. 2010, 105, 1301-1319. [CrossRef]

28. Al-Malabeh, A.; Kempe, S.; Henschel, H.-V.; Hofmann, H.; Tobschall, H.J. The possibly hypogene karstic iron ore deposit of Warda near Ajloun (Northern Jordan), its mineralogy, geochemistry and historic mine. Acta Carsologica 2008, 37, 241-253. [CrossRef]

29. Hauptmann, A. The Archaeometallurgy of Copper: Evidence from Faynan, Jordan; Springer: Bochum, Germany, 2007; ISBN 978-3-540-72237-3.

30. Xuejing, X.; Mingcai, Y.; Lianzhong, L.; Huijun, S. Usable Values for Chinese Standard Reference Samples of Stream Sediments, Soils, and Rocks: GSD 9-12, GSS 1-8 and GSR 1-6. Geostand. Newsl. 1985, 9, 277-280. [CrossRef]

31. Certificate of Certified Reference Materials. NCS DC 73014—NCS DC73022; Stream Sediment: Beijing, China, 2010.

32. Levin, E.M.; Robbins, C.R.; McMurdie, H.F. Phase Diagrams for Ceramists, 1st ed.; The American Ceramic Society Inc.: Columbus, OH, USA, 1964.

33. Folkhard, E. Welding Metallurgy of Stainless Steels, 1st ed.; Springer Science: New York, NY, USA, 2012; ISBN 978-3-7091-8965-8.

34. Park, J.-S.; Reichert, S. Technological tradition of the Mongol Empire as inferred from bloomery and cast iron objects excavated in Karakorum. J. Archaeol. Sci. 2015, 53, 49-60. [CrossRef]

35. Paynter, S. Innovations in bloomery smelting in Iron Age and Romano-British England. Metals and mines. In Metals and Mines: Studies in Archaeometallurgy; La Niece, S., Hook, D.R., Craddock, P., Eds.; Archetype, British Museum: London, UK, 2007; pp. 202-210. ISBN 9781904982197.

36. Mukhopadhyay, D.K.; Lindsley, D.H. Phase relations in the join kirschsteinite $\left(\mathrm{CaFeSiO}_{4}\right)-\mathrm{fayalite}\left(\mathrm{Fe}_{2} \mathrm{SiO}_{4}\right)$. Am. Mineral. 1983, 68, 1089-1094.

37. Ströbele, F.; Wenzel, T.; Kronz, A.; Hildebrandt, L.H.; Markl, G. Mineralogical and geochemical characterization of high-medieval lead-silver smelting slags from Wiesloch near Heidelberg (Germany)—An approach to process reconstruction. Archaeol. Anthropol. Sci. 2010, 2, 191-215. [CrossRef]

38. Kronz, A. Phasenbeziehungen und Kristallisationsmechanismen in fayalitischen Schmelzsystemen: Untersuchungen an Eisen-und Buntmetallschlacken; Klaus Bielefeld Verlag: Friedland, Germany, 1997; ISBN 3-932325-16-8.

39. Crew, P. Twenty-five years of bloomery experiments: Perspectives and prospects, Accidental and Experimental Archaeometallurgy. In Accidental and Experimental Archaeometallurgy; Dungworth, D., Doonan, R., Eds.; Historical Metallurgical Society: London, UK, 2013; pp. 25-50. ISBN 978-0956022516.

40. Deer, W.H.; Howie, R.A.; Zussman, J. An Introduction to Rock-Forming Minerals, 2nd ed.; Longman Scientific \& Technical: Essex, UK; Willey: New York, NY, USA, 1992.

41. Eekelers, K.; Degryse, P.; Muchez, P. Petrographic investigation of smithing slag of the Hellenistic to Byzantine city of Sagalassos (SW-Turkey). Am. Mineral. 2016, 101, 1072-1083. [CrossRef]

42. Kucha, H.; Waelkens, M.; Viaene, W.; Laduron, D. Mineralogy, geochemistry and phase equilibria as tracers of the technology of iron (steel) making at Sagalassos during the Roman period. In Sagalassos III. Report on the Fourth Excavation Campaign of 1993; Waelkens, M., Poblome, J., Eds.; Leuven University Press: Leuven, Belgium, 1995; pp. 273-291. 
43. Leroy, M.; Le Carlier, C.; Merluzzo, P. Entre bas et haut fourneau. L'utilisation de la minette de Lorraine au Moyen Age: Une parfaite adéquation avec la technique du bas fourneau. In Proceedings of the Actes du 4è Congrès International d'Archéologie Médiévale et Moderne, Paris, France, 3-8 September 2007; INHA: Paris, France, 2007; pp. 1-18.

44. Ben-Yosef, E.; Shaar, R.; Tauxe, L.; Ron, H. A new chronological framework for Iron Age copper production at Timna (Israel). Bull. Am. Sch. Orient. Res. 2012, 367,31-71. [CrossRef]

45. Avner, U.; Ginat, H.; Shalev, S.; Shilstine, S.; Langford, B.; Frumkin, A.; Shem-Tov, R.; Filin, S.; Arav, R.; Basson, U.; et al. Ancient copper mines at Nahal Amram, Southern Arabah. In Mining for Ancient Copper. Essays in Memory of Beno Rothenberg; Ben-Yosef, E., Ed.; Tel-Aviv University: Tel-Aviv, Israel, 2018; pp. 147-177. ISBN 978-1575069647.

46. Piatak, N.M.; Parsons, M.B.; Seal, R.R., II. Characteristics and environmental aspects of slag: A review. Appl. Geochem. 2015, 57, 236-266. [CrossRef]

47. Gee, C.; Ramsey, M.H.; Maskall, J.; Thornton, I. Mineralogy and weathering processes in historical smelting slags and their effect on the mobilisation of lead. J. Geochem. Explor. 1997, 58, 249-257. [CrossRef]

48. Veldhuijzen, H. Early Iron Production in the Levant. Ph.D. Thesis, Institute of Archaeology, Unviersity College London, London, UK, 2005.

49. Brauns, M.; Yahalom-Mack, N.; Stepanov, I.; Sauder, L.; Keen, J.; Eliyahu-Behar, A. Osmium Isotope Analysis as an Innovative Tool for Provenancing Ancient Iron: A Systematic Approach. PLoS ONE 2019. Accepted for publication.

(C) 2019 by the authors. Licensee MDPI, Basel, Switzerland. This article is an open access article distributed under the terms and conditions of the Creative Commons Attribution (CC BY) license (http://creativecommons.org/licenses/by/4.0/). 